\title{
Review of social protection experiences in Sub-Saharan Africa: The case of Eritrea
}

\section{Gebremichael Kibreab Habtom}

Department of Management and Public Administration, College of Business and Social Sciences, P.O. Box 12492, Adi Keih, Eritrea

DOI - http://doi.org/10.37502/IJSMR.2022.5107

\begin{abstract}
The study reviews the major challenges of social protection programs of Eritrea with regards to financing, institutional capacity and political support. The data for study was partially taken from the studies conducted in the ministry of labor and Social welfare in May 2019 and November 2020. Both studies used survey and case study methodologies. The study seeks to answer the following two research questions: what are the challenges of the social protection programs in Eritrea? And what lessons can be learned from the experience of Sub-Saharan African countries? To answer these questions a deductive approach was adopted in this study methodology. To this end Sub-Saharan African countries experience of social protection programs are reviewed and analyzed in general and the social protection programs of Eritrea in particular. In this study it is found that in Eritrea social protection programs are less integrated into national plans, inter sectoral coordination and collaboration among government ministries and civil societies is low, budget allocated to social protection programs are in adequate, technical and institutional capacities are in sufficient to develop and administer social protection programs, reliable data on which policies on social protection can be based is hardly available, monitoring and evaluation systems are inadequate :and information dissemination on availability of existing social protection programs are limited. The government should adop and implement broad based social protection policies to mitigate and counteract all sources of vulnerability including chronic crop failure, health epidemics, environmental disasters and other external shocks, and align social protection programs to family policy on education, health, housing and food security. It is believed that the basic strategies and policies of social protection programs of Sub-Saharan African countries would provide a good lesson for developing countries like Eritrea. Eritrea can learn a lot from the experience of Sub-Saharan African countries, both success and failure stories of social protection systems.
\end{abstract}

Keywords - social protection, protection programs.

\section{Introduction}

Eritrea is an East African country, which is bordered with Ethiopia in the south, with Sudan in the north and the west, with Djibouti in the southeast, and with the Red Sea in the east. Eritrea got independence from Ethiopia in 1993 after 30 years of armed struggle. Eritrea's 
population is estimated to be about six million, with an average life expectancy of 64.7 years and a literacy rate of $67.5 \%$ (WHO, 2016). Demographically Eritrea is a young population, with 42.2 percent below 15 years of age and only 6.7 percent being in 65 years and above, resulting in age dependency ratio of 96 percent (MLHW, 2018). Eritrea's economy is largely dominated by subsistence agriculture. About $70 \%$ of the Eritrean people depend on farming and herding for its livelihood and live in countryside. The population density ranges from 36.3 to 40.6 people per sq. km (World Bank, 2002).

In Eritrea social protection is a critical component of the Human Development Pillar of the national development strategy alongside Health, Education, and Water and Sanitation. It also cuts across other sectors and supports the achievement of wider development objectives. Improving the quality of life for persons living under the internationally established poverty line, while at the same time caring for the specific problems of vulnerable groups, are primary challenges to which a robust social protection policy must respond.

The need for social protection in Eritrea is driven by the fact that, irrespective of socioeconomic status, all people are faced with various risks and vulnerabilities over their lifetime, which could render them unable to meet their basic needs such as food, clothing, housing, health care and education. Social protection strengthens the capacity of the vulnerable persons and their families meet basic needs, build resilience, access opportunities and improve livelihoods. In Eritrea, there are various social protection programmes that ensure access to services, such as free education at all levels, free public health and medical services, school feeding programs at remote villages and distribution of subsidized basic necessities mostly food items like bread, cereals, cooking oil, sugar, etc. There are also social care and support services such as child protection, care for older persons and the chronically sick, community-based rehabilitation for persons with disabilities, and mitigation of gender-based violence. These social protection services improve the quality of life of these vulnerable groups and promotes inclusive development.

There is increasing evidence that social protection not only reduces poverty among direct beneficiaries and their households but also improves wealth distribution and underpins economic growth within local communities by conserving national fiscal resources. This makes comprehensive social protection policy an attractive instrument for poverty reduction in Eritrea. At the household level, predictable social transfers provide more than just welfare and can positively improve the livelihoods and productivity of the poor, by encouraging them to enter the labour market. They can also increase access of household members to education and health services which has long term benefits and helps to break the inter-generational transmission of poverty.

In this study social protection is defined as the set of measures that a society provides for its members to protect them from general poverty and social exclusion, from a lack of income caused by sickness, disability, maternity, employment injury, unemployment, old age, death of a family member, a lack of affordable access to health care, and insufficient family support, particularly for children and adult dependants (ILO \& UN Development Group, 2016). In the traditional African setting, this concept was defined by solidarity and mutual 
support among societies, and it had the primary aim of helping individuals to maintain a certain minimum standard of living especially when faced with social as well as economic and general livelihood contingencies (Mchomvu et al, 2002). In this case social protection is both an approach and a set of policies. As an approach, it focuses on reducing risk and vulnerabilities, and includes 'all interventions from public, private and voluntary organisations and informal networks to support communities, households and individuals in their efforts to prevent, manage and overcome risks and vulnerabilities'. As a policy it reflects a complex interaction of factors (e.g. interaction of poverty and vulnerability with politics and ideology) that constitute the social and political context of a nation.

This study, therefore, examines the major challenges of the social protection system in Eritrea with regards to financing, institutional capacity and political support. The study seeks to answer the following two research questions: what are the challenges of the social protection system in Eritrea? And what lessons can be learned from the experience of social protection systems of Sub-Saharan Africa? To answer these questions, a deductive approach was adopted in this study methodology. To this end Sub-Saharan African countries experience of the social protection systems are carefully reviewed and analysed, in general, and the social protection system of Eritrea in particular. It is believed that the basic strategies and policies of social protection systems of Sub-Saharan African countries can provide a good lesson for developing countries like Eritrea. Eritrea can learn a lot from the experience of Sub-Saharan African countries, both success and failure stories of social protection systems.

\section{Conceptual Framework- Social Protection Approaches}

The study follows the globally and mutually accepted conceptual frameworks and approaches of social protection, which are adopted by international bodies implementing SP such as United Nations (UN), International Labour Organization (ILO) and World Bank (WB). These are the social risk management framework, the Transformative Social Protection framework, and the life cycle approach. According to Haddad (2007) the Social Risk Management (SRM) framework is grounded in two main principles: "people with low incomes are more exposed to shocks and have fewer market and state instruments to be able to prevent and mitigate risks". This framework contends that this exposes the poor to risks and vulnerabilities as well as limits their engagement in profitable, but risky, activities-potentially diminishing human capital and productive capabilities. Holzmann and Kozel, (2007) noted that the provision of risk management instruments is one of the most effective strategies to achieve poverty reduction, income stabilization, consumption stabilization and asset accumulation. The framework proposes that the development of national social protection systems should begin by profiling risks specific to national contexts to best understand country-specific vulnerabilities. SRM identifies three main risk management strategies to include in a social protection system: risk reduction, risk mitigation and risk coping. It employs these strategies to protect populations against shocks, rather than promoting general equity or minimum guarantees.

On the other hand the Transformative Social Protection (TSP) framework provides a more developmental alternative to the SRM approach. This framework reconceptualises the nature 
of vulnerability by addressing the increasingly important socio-political drivers that cause and perpetuate poverty and vulnerability to risk (OECD, 2019). The TSP provides a fourcomponent model of social protection tools: the first part includes provision tools such as social transfers and access to basic social services; the second module, prevention, includes measures to prevent deprivation such as social insurance, informal saving clubs and risk diversification schemes; the third component, promotion, consists of livelihood support measures that aim to lift people out of poverty, such as microcredit programs, public works and school feeding programs; and the fourth element, transformation, tackles social structures that perpetuate poverty and social exclusion through legislation reform, antidiscrimination (Taylor, 2008; UN, 2001).

Figure 1: Two Perspectives on the Social Protection System

Life Cycle: Demand View

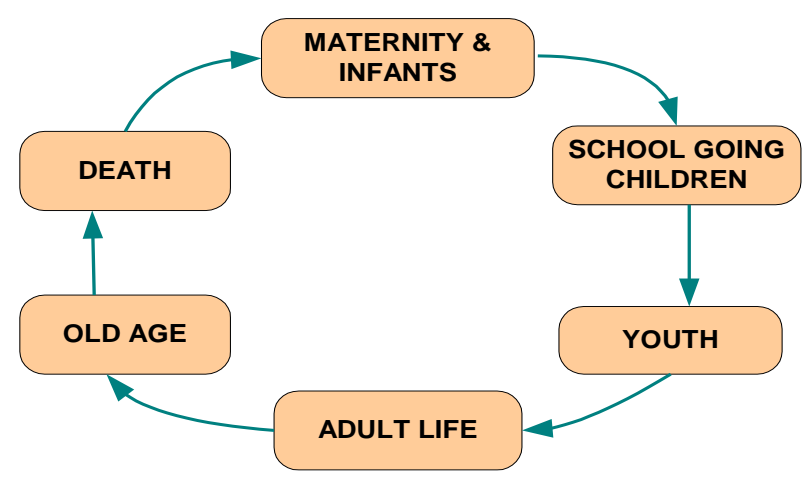

Social Protection Functions: Supply View

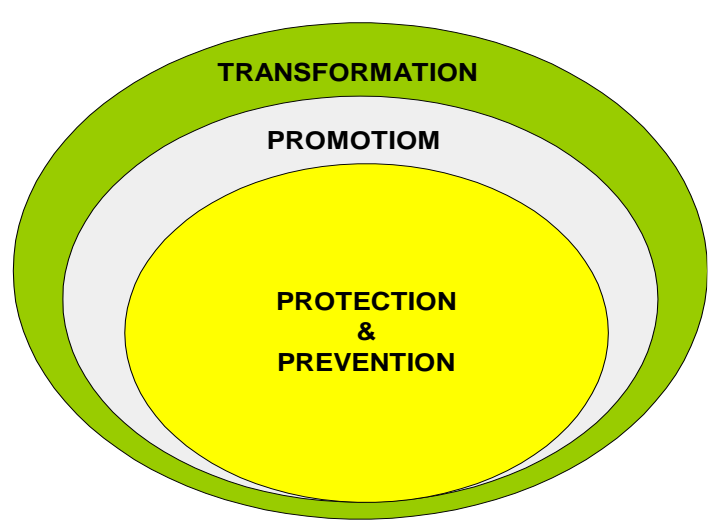

Source: Author's design

As shown in figure 1, social protection systems can be seen from two perspectives- the life cycle (demand view) and social protection function (supply view). The Life Cycle approach to social protection derives from the idea that individuals face different risks and vulnerabilities at different stages in life, and that social protection can be tailored to address these risks at each stage.

Life cycle changes that result from negative shocks in social or economic status lead an individual to enter a new lifecycle marked by higher levels of risk and vulnerability. Social protection instruments can address shocks as they occur, protecting individuals from negative life-cycle changes (OECD, 2019). The social protection function, on the other hand, tries to address individual risks and vulnerabilities through transformation, promotion, protection and prevention. In Eritrea, protective measures are designed to save lives and reduce deprivation levels while preventive measures are reducing people's exposure to risks through social insurance programs such as pensions and health insurance. Promotive measures on the other hand enhance the capability of the vulnerable to protect themselves against hazards and loss of income; and transformation measures are designed to reduce inequities and improve social integration through changes in laws, budgetary allocations and redistributive measures. 
Figure 2: Conceptual Framework - Mapping Multiple Vulnerabilities across the Life-Cycle in Eritrea

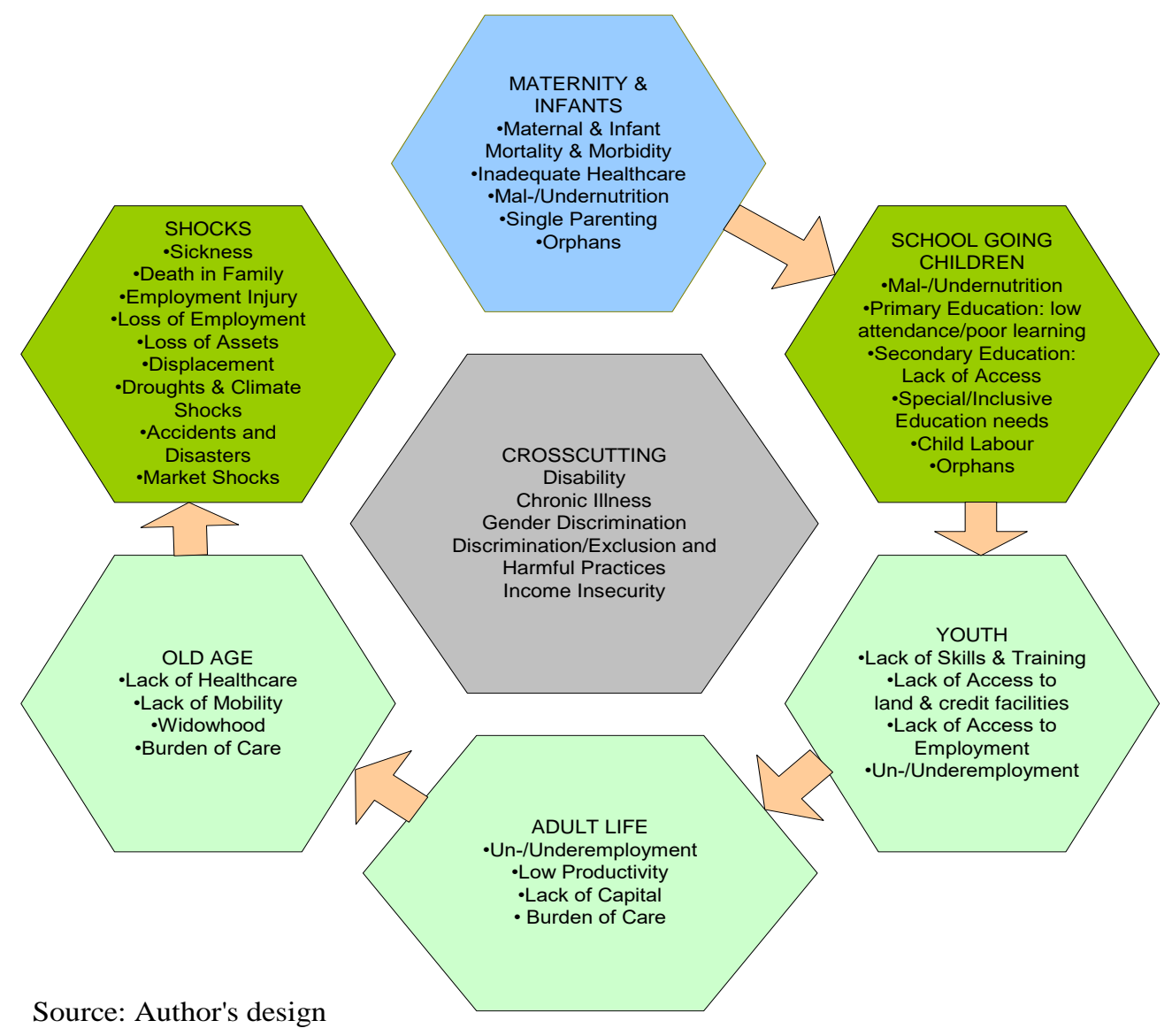

The multidimensional nature of poverty, in developing countries, requires a comprehensive social protection system which meets the needs of the most vulnerable groups particularly children, women, people with disabilities, the elderly and also people affected by HIV and AIDS. The conceptual framework for social protection is, therefore, designed in such a way that to show the mapping of multiple vulnerabilities across the life cycle in Eritrea (see figure 2). Social protection in this regard provides a unique opportunity for making a difference in the lives of the most vulnerable segments of the population.

For developing countries, like Eritrea, social protection helps to achieve 14 of the 17 sustainable development goals (SDGs). Social protection, tackles poverty and inequality (Goals 1 \& 16), strengthens food security (Goal, 2), improve health and cognitive development (Goals, $3 \& 9$ ), strengthens education outcomes (Goal, 4), promotes gender equality (Goal, 5), enables better household level environmental management (Goals, 6 \& 13), strengthens social inclusion and cohesion (Goals, $11 \& 16$ ), fosters inclusive growth, decent work and productive employment (Goal, 8), improves macroeconomic resilience (Goal, 12), and strengthens opportunities for development partnerships (Goal, 17) (OECD, 2019). To achieve the SDGs a nationally defined social protection floor that guarantees access to health care and at least a basic level of income security throughout the life course is critical. 


\section{A Review of Social Protection Experiences in Sub-Saharan Africa}

Most developing countries do not have comprehensive social protection programs. The 2014 ILO Report on World Social Protection (ILO, 2014:1) notes that only 27\% of the global population enjoys a comprehensive social protection cover with the remaining $73 \%$ only being covered partially or not at all. In Africa, it is estimated that $70 \%$ of the population lacks access to any form of social protection (World Bank, 2012). While there is universal social protection coverage for people in high-income countries, four in every five people in Low Income Countries, and nine in every ten people in Sub-Saharan Africa (SSA) have no basic social protection (ILO 2008, 2010; ISSA 2008). It is only in recent years that social protection has started to feature prominently on the political agenda in SSA countries (NinoZarazua et al 2010; Ellis et al 2009; Adato and Hoddinott 2008).

The social protection experience of Sub-Saharan African countries is reviewed taking into account the five major elements of social protection programs: social security, social assistance, labour markets, micro and area-based schemes to protect communities and child protection. Sub-Saharan African countries face the greatest challenge in this regard taking into account the fact that more than half of the population live in extreme poverty (less than US $\$ 1.25 /$ day/capita), and almost three-quarters (73 per cent) living on less than US $\$ 2$ per day (Horman, 2012). Most of the time this raises a common objection when it comes to introducing elements of social protection in Sub-Saharan African countries because majority of African countries are not economically mature enough to shoulder the financial burden associated with social protection. Contrary, Ortiz (2007) argued that in countries where the poor represent a significant proportion of the population, public universal provision is the best solution for primary/secondary education and health, and basic social protection. There is a strong rationale for adopting universal policies in developing countries, particularly if a large number of poor and excluded groups exist. A number of development organizations, including UN DESA, UNDP, ILO, WHO, UNRISD, UNFPA, UNESCO, and the World Bank in selected instances, are currently recommending universal public provisioning.

\section{Social Security}

Social security in SSA covers only a minority of the workforce. Large segments of the labour force remain outside the reach of social security and are also not covered by any other forms of social protection. ILO Convention 102 defines nine (9) benefits to be provided by every social security system. These are old age, invalidity, survivor's benefits (commonly referred to as pensions), unemployment benefits, maternity benefits, medical care (health insurance), employment injury, family allowance, and sickness benefits. SSA countries tend to offer very limited social security benefits to those who are covered. Out of the 9 benefits stipulated in ILO Convention 102, most schemes in SSA offer only three benefits: survivor, disability and old age pension. Most Anglophone African countries provide only old age pension and related invalidity and survivors' benefits and pay very low pensions, making it difficult for pensioners to adequately smooth their consumption and protect themselves and their families from the risk of poverty (Otoo \& Clara Osei-Boateng, 2012). 
For the whole of SSA, the average coverage rate is just about 6 percent compared to the global average of 25 percent (Forteze et.al, 2010). And the coverage rate continues to fall for many countries as formal employment shrinks and informality becomes the dominant form of employment. Mauritius has the highest coverage rate in SSA with about 50 percent of the labour force covered followed by Cape Verde which has a coverage rate of 27 percent (Otoo $\&$ Clara Osei-Boateng, 2012). All other countries have coverage below 20 percent with the majority falling below 10 percent of the labour force. For example, in countries such as Chad, Mozambique, Burkina Faso, Niger, Nigeria and Burundi, the mandatory employment-based insurance covers less than five per cent of the total labour force (Horman, 2012).
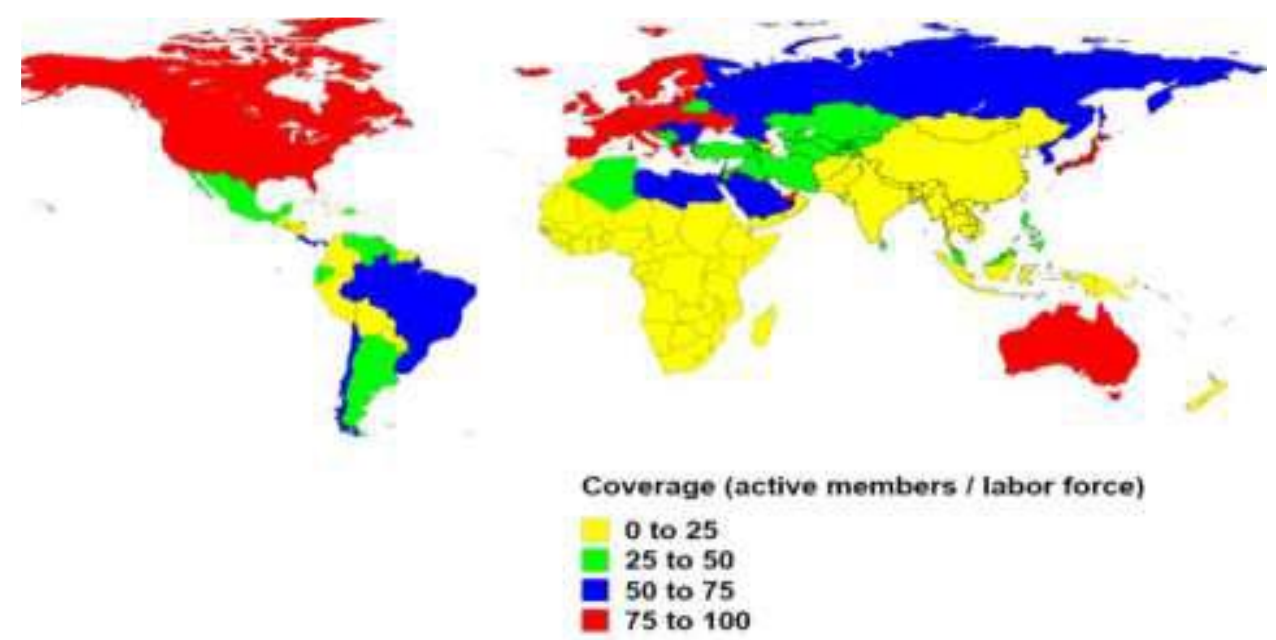

Source: Otoo, KN \& Clara Osei-Boateng (2012). Social Protection Schemes in Africa, Edited by Trywell Kalusopa, Rudi Dicks, and Clara Osei-Boateng. http://www.itcu-africa.org

\section{Figure 3: Social Security Coverage around the World (\% labour force)}

The low coverage of social security in SSA reflects the declining trend of formal employment on the continent. As shown in figure 3, most countries in SSA adopted or inherited mandatory contributory schemes at independence. These schemes (contributory) are based on the assumption that as economies developed, more of the labour will secure employment in the formal sector where productivity and earnings would be high enough to afford workers some saving capacity. This would make it possible for the state to enforce social security contributions. In most SSA countries, however, economic growth has failed to pull the labour force into formal employment. Informal employment has expanded in nearly all countries in Africa and a significant majority of the workforce is trapped in low-productivity employment in the agricultural sector. Overall, more than half of the labour force in SSA is in selfemployment. In some countries such as Ghana, Kenya, Burkina Faso, Nigeria and Sierra Leone, nearly nine of ten workers are employed in the informal economy (Otoo \& Clara Osei-Boateng, 2012). And far from declining, informality is on the rise everywhere in SSA as nearly all new jobs are created in the informal sector. These groups of workers earn very little that enforcing mandatory contributions on them appears not feasible.

The exclusion of the informal sector from public social security schemes presents issues of gender inequity and vulnerability. The informal sector in Africa is dominated by women and 
young people. The proportion of females in informal employment is estimated at 57 percent in Ghana, 65 percent in Benin, 58 percent in Malawi and 53 percent in Namibia (Baah, 2007). Thus the exclusion of the informal sector amounts to denying women and the youth access to social security. And obviously, inadequate protection for women and the youth expose them to unmitigated risks that tend to push them into poverty which perpetuates throughout their working life and retirement.

Recently, the issue of social protection has gained greater importance as it has been increasingly seen as essential to poverty reduction. Some countries in Africa such as Ghana and Senegal are in the process of reviewing their social protection policies with the aim of making them more responsive to their evolving situations. In Djibouti Social security reform plan is underway to extend coverage to workers in the informal sector and their families and sickness insurance for all nationals. In Côte d'Ivoire studies are carried out to look on possibilities to extend coverage to self-employed workers. In Ethiopia there are plans to extend coverage to private sector employees' pensions and establishment of a health insurance scheme. In Sudan there are plans for universal health insurance for all citizens. The Ministry of Social Welfare has a three-phase plan, which includes developing the benefits under the social security funds, those provided under the Zakat Chamber and assistance under the social solidarity project. In the United Republic of Tanzania introduction of a universal old-age pension and access to medical care for all on a means-tested basis is under consideration. Gradual compulsory membership of self-employed workers is a possible means of ensuring coverage of a large proportion of the population not yet benefiting from any social security coverage. State support in the form of social contribution subsidies would be an important component to ensure the success of such initiatives. Nowadays social insurance programs are provided in South Africa, and Tunisia through contributory occupational pension, in Burkina Faso through Mutual Health insurance, in South Africa through unemployment benefits, in Tunisia through contributions to the National Social Security Fund, in Mauritius through unemployment hardship relief, and in South Africa and Tunisia through disability pension -contributions to the National Social Security Fund (Horman, 2012).

\section{Social Assistance}

Social assistance to the vulnerable protection and mitigation through cash transfers are practiced in Mozambique through national institute of social action, in Ethiopia through productive safety nets program, in Kenya through cash transfer program for orphans and vulnerable children, and in Zambia through Kalomo pilot (HelpAge International \&AU, 2008). Social assistance to the vulnerable protection and mitigation through food transfers to the destitute is practiced in Ethiopia, Gambia, Liberia and Malawi (Holmes \& Jackson, 2008). Social assistance to the vulnerable protection and mitigation through food security input packs is used in Zambia, Malawi, and Ethiopia (United States Social Security Administration, 2007). There are also a fair number of African countries that provide social pension for older persons such as Botswana - Old-age pension (universal), Lesotho - Noncontributory old-age pension scheme, Liberia - Old-age assistance, Mauritius - Old-age pension (universal), Namibia - Old-age pension, South Africa - Old-age pension (means 
tested); child support grant such as Botswana - Orphan care benefit system, Mozambique Minimum Income for School Attendance, South Africa - Child Support Grant, Care dependency grant; and disability grant such as Liberia - Disability assistance, Mauritius Basic disability pension, South Africa - Disability grant (means tested) (Cirillo and Tebaldi, 2016). Comparing to other African countries South Africa provides a wide range of promotive and transformational social assistance such as targeted free health care for pregnant women, children under six years and the poor; targeted free school for the very poor; access to low cost housing; free targeted quota of municipal services to the poor for electricity, water and sanitation; and social services and residential care for children, older persons and persons with disabilities (Holmes \& Jackson, 2008).

Table 1. List of programs by country

\section{Country Type of Interventions}

Algeria Solidarity Allowance, Intervention for Social Inclusion, and Labor-Intensive Public Works.

\begin{tabular}{ll}
\hline Angola & Card cash transfer program, and School Feeding Program \\
\hline Botswana & Destitute Persons Allowance, Public Works, National Orphan Care Program, \\
& Old Age Pension, School Feeding Program, Vulnerable Group Feeding \\
& Program, and World War II Veterans Allowance
\end{tabular}

Burkina Nahouri Cash Transfers Pilot Project

Faso

Cameroon Cameroon Social Safety Nets Projects

Cape Verde Frentes de Alta Intensidade de Mão-de-Obra (FAIMO), and Pensão SocialSocial Pension

\begin{tabular}{ll}
\hline Comoros & Argent Contre Travail (ACT)-Cash for Work \\
\hline $\begin{array}{l}\text { Republic of } \\
\text { Congo }\end{array}$ & LISUNGI Safety Nets Project \\
\hline &
\end{tabular}

Djibouti Program National de Solidarité Famille (PNSF)

Egypt National Program of Family Solidarity, Food and Energy Subsidies, School Feeding Program, Social Solidarity Pension, and Takaful and Karama (Solidarity and Dignity).

\begin{tabular}{|c|c|}
\hline Ethiopia & $\begin{array}{l}\text { Productive Safety Net Program, School Meals Program, Tigray Social Cash } \\
\text { Transfer, and Pilot Program }\end{array}$ \\
\hline Gambia & Family Strengthening Program \\
\hline Ghana & $\begin{array}{l}\text { Ghana's National Health Insurance, Scheme Fee Exemptions, Ghana School } \\
\text { Feeding Program, Labour Intensive Public Works-LIPW (under Ghana } \\
\text { Social Opportunities Project-GSOP), and Livelihood Empowerment Against } \\
\text { Poverty (LEAP) }\end{array}$ \\
\hline Guinea & $\begin{array}{l}\text { Cash transfer for health, nutrition and education, and labour intensive public } \\
\text { works program }\end{array}$ \\
\hline Ivory coast & Temporary Employment Opportunities for Youth \\
\hline Kenya & $\begin{array}{l}\text { Cash Transfers for Orphans and Vulnerable Children, Health Insurance } \\
\text { Subsidy Program, Home Grown School Meal, Hunger Safety Net Program, }\end{array}$ \\
\hline
\end{tabular}


Kenya Youth Empowerment Project, National Accelerated Agricultural Input Program, Njaa Marufuku Kenya (NMK)-School Feeding Program, Older Persons Cash Transfer, and Persons with Severe Disability Cash Transfer Lesotho Agricultural Input Fairs: Input Vouchers for the Poor, Child Grants Program, Old Age Pension, OVC Bursary, Public Assistance, and School Feeding Program.

Liberia School Feeding Program, Social Cash Transfer Program, and Youth, Employment, Skills

Madagascar Argent Contre Travail-Cash for Work, Le Transfert Monétaire ConditionnelConditional Cash Transfer, and School Feeding Program Malawi $\quad$ Farm Input Subsidy Program, Improved Livelihoods Through Public Works Program, Social Cash Transfer

Mali Jigisemejiri - "Tree of Hope" program, Régime d'Assistance Médicale, and School Feeding Program.

Mauritania Prise en charge des soins de santé des indigents-Indigent Health Coverage. Mauritius Basic Invalidity Pension and Carer's Allowance, Basic Orphan's Pension, Basic Retirement Pension (Universal Old Age Pension) and Caregiver's Allowance, Basic Widow's Pension, Child's Allowance, Guardian's Allowance, Inmate's Allowance, and Social Aid \& Unemployment Hardship Relief

Morocco Direct assistance to widows in a precarious situation with dependent children (Cash transfer program), Food and Butane Gas Subsidies Program, Morocco's Cash Transfer for Children (Tayssir Program), and Regime for Medical Assistance to the most deprived

Mozambique Basic Social Subsidy Program, and Labour-Intensive Public Work Namibia Child Maintenance Grant, Disability Grant, Foster Care Grant (or Foster Parent Grant), Namibia School Feeding Program, Old age pension, Place of Safety Allowance, and Special Maintenance Grant

Niger Cash Transfers for Food Security and Cash for Work (under the Niger Safety
Net Project-Filet de Protection Sociale)

Nigeria Ekiti State Social Security Scheme, Home Grown School Feeding and Health Program, In Care of the Poor, Osun Elderly Persons Scheme, SURE-P:

Community Services Women and Youth Employment, and Maternal and Child Health

Rwanda Genocide Survivors Support and Assistance Fund, Girinka, the One Cow Per Poor Family Program, Rwanda Demobilization and Reintegration Program, Vision 2020 Umurenge Program.

Senegal Conditional Cash transfer for Orphans and Vulnerable Children, and Program National de Bourses de Sécurité Familiale

Sierra Leone Social Safety Net Program, and Cash for Work

South Africa Care Dependency Grant, Child Support Grant, Disability Grant, Expanded

Public Works Program, Foster Child Grant, Grant-in-Aid, National School

Nutrition Program, Older Persons Grant, and War Veteran's Grant 


\begin{tabular}{ll}
\hline Swaziland & Old Age Grant, and Public Assistance Grant \\
\hline Tanzania & Community-Based Conditional Cash Transfer, Food for Education Program, \\
& Food Subsidies, Tanzania Social Action Fund, and Productive Social Safety \\
& Net Program. \\
\hline Togo & School Feeding Program, Cash Transfer Program for Vulnerable Children in \\
& Northern Togo, and Labour-Intensive Public Works \\
\hline Tunisia & Programme National d'Aide aux Familles Nécessiteuses (PNAFN) \\
\hline Uganda & Direct Income Support under the Expanding Social Protection Program, \\
& Second Northern Uganda Social Action Fund Project, and Livelihood \\
& Investment Support Component \\
\hline Zambia & Food Security Pack, Home Grown School Feeding Program, Public Welfare \\
& Assistance Scheme, and Social Cash Transfer Program \\
\hline Zimbabwe & Assisted Medical Treatment Order, Basic Education Assistance Module, \\
& Harmonized Social Cash Transfer, and Public Assistance Monthly \\
& Maintenance Allowance \\
\hline
\end{tabular}

Source: Cirillo, C. and Tebaldi, R. (2016).Social Protection in Africa: Inventory of Non-Contributory Programs. International Policy Centre for Inclusive Growth. United Nations Development Programme

The countries of North Africa, for instance, have experienced the broadest extension of Bismarckian social insurance - relating to protections against old age, sickness and employment injury, as well as the provision of family allowance - initially under the colonial regime and continuing post-independence (François-Xavier Merrien, 2013).

\section{Labour market}

Labour market programs are another version of social assistance to the vulnerable protection and mitigation through micro-credit schemes such as in Zambia and Mozambique and through public works such as in Zambia, Sierra Leone, Ethiopia, Malawi and South Africa (Otoo \& Clara Osei-Boateng, 2012). Labour market policies and programmes are important to reduce poverty, facilitate human capital development, address discrimination, enhance working conditions, allocate human resources to their most productive uses, and encourage growth and development. In this regard active labour market programmes include direct employment generation (promoting small and medium enterprises, cooperatives, wage subsidies, public works, guaranteed job schemes); labour exchanges or employment services (job brokerage, counselling offices); skills development programmes (training and retraining of labour to enhance employability and productivity); and special programmes for youth and persons with disabilities (Ortiz, 2007).

Employment generation, however, is necessary but not sufficient condition for poverty reduction; many people in developing countries work long hours for insufficient pay, under bad working conditions and are not able to bring their households out of poverty. This is why the ILO introduced the "decent work agenda" in 1999 (Ortiz, 2007). It involves fair income, standards in the workplace, social protection for all, skills development for enhanced productivity, and social dialogue. 


\section{Informal Arrangements for Social Protection}

The large majority of Africans excluded from social security have mainly depended on informal arrangements for social protection. Traditionally, most Africans have largely relied on the support of the extended family to meet life contingencies. Parents depend on the support of their children during retirement. Extended family members provide support for the aged and the disabled, the sick and the unemployed members of the family, the new born child and the mother, the orphaned and even the complete stranger (Kumado and Gockel, 2003). However, growing economic constraints and urbanization have affected kinship ties and ability for family members to provide support. More often, members of the family are either too poor themselves or have other competing demands for their resources.

Mutual help associations have provided avenue for sharing financial risks among operators in the informal sector. These associations are usually the initiative of community members or non-governmental organizations. Based on insurance principles, contributors pool resources together to meet life contingencies. The common benefits shared through mutual associations among informal sector operators include medical care and funeral cost. Traditional saving mechanisms have become important social security schemes. Although these mechanisms are primarily microfinance savings and credit schemes, they serve social security purposes, since the proceeds are also used to meet health care needs and unemployment burdens, among others. Microfinance savings schemes are very common across the continent. The rotating savings scheme termed 'susu' in Ghana, 'osusu' in Sierra Leone, 'eso dzodzo' in Togo, 'tontine' in Benin and 'upatu' in Tanzania operates not only among informal sector operators but also among formal sector workers (Kumado and Gockel, 2003).

\section{Methodology}

The data for this study was partially taken from the studies conducted in the Ministry of Labour and Social Welfare in May 2019 (SP mapping study) and November 2020 (SP policy and strategic plan studies). Both studies used survey and case study methodologies. In both studies data was collected from primary and secondary sources. The main sources of secondary data were various documents from line ministries, local NGOs, national associations, regional administrations, development partners, international organizations, case studies and experiences of some African countries inter alia with various UN, ILO, World Bank documents and other related materials on social protection. Further moreover, a comprehensive review of the literature on social protection in Eritrea was carried out, including an analysis of policy and strategy documents, social protection program documents, annual reports and impact evaluations.

Primary data was collected by interview and focus group discussions. Consultations, Key Informant Interviews and Focus Group Discussions were conducted with relevant line ministries, regional administrations, key development partners, local NGOs, national associations and other stakeholders. Focus Groups Discussions (FGDs) were conducted in five regions of the country. The focus groups consisted of about 20-25 participants that are responsible for managing social protection programs or beneficiaries of social protection 
programs. Both studies took gender into consideration and in most cases the participation of women was adequately ensured. Finally, the qualitative data was transcribed and analysed according to themes and indicators identifying patterns in participants' responses in light of the social protection and strategy of concern: poverty, vulnerability, access to social protection, delivery mechanisms, challenges and gaps in social protection, etc.

\section{Review of social protection programs in Eritrea}

The Government of State of Eritrea (GoSE) recognizes that many Eritrean citizens can face risks or disasters through the course of their lives. Such risks include natural disaster such as drought, crop failure, illness; occupational injury, loss of income at old age and death of bread winner of poor households. The fact that, in Eritrea, the poor constitute about $66 \%$ of the population, (or 2.36 million), of which $37 \%$ are extreme poor-living below the food poverty threshold and about 67 percent of the poor live in rural areas of which about 39 percent are extreme poor (GoSE, 2004). The poor not only have low levels of income and expenditure, but they also have more limited access to public infrastructure and basic social services including education, health, clean drinking water, and proper sanitation (ibid). Such limited access undermines their capabilities and severely limits their potential to secure gainful employment, and results in income poverty.

The Government of the State of Eritrea is committed to the betterment of the livelihoods and the well-being of all Eritrean citizens, particularly for the poor and vulnerable social groups through implementation of various social protection programs. Taking in to account that many Eritreans are likely to face various risks in their life cycle, there is dire need to expand the scope of social protection programs that help vulnerable individuals, households, and communities to cope to the risks they face or that provide support to the critically poor and vulnerable to build their economic capability to create Eritrean society well protected from poverty and vulnerability.

The Social Protection (SP) programs in Eritrea are supported by various policies such as health policy, education policy, labour proclamations, Policy for People with Disabilities, Child policy, Pension scheme for civil servants, etc. All of these policies emanate from the Government's political commitment to protect its citizens from vulnerabilities and its dedication to the promotion of the principles of social justice. For instance, the Growth strategy of the National Charter of the Peoples Front for Democracy and Justice calls for: (i) creation of income earning opportunities for the poor; (ii) enhancing access to and utilisation of essential services for human development; (iii) promotion of the political, economic and social participation of the population; and (v) creation of an environment for economic growth and development. Along the same lines the Ministry of Labour and Human Welfare (MLHW) is working towards the fulfilment of the rights to access of basic services and achievement of an adequate standard of living for the Eritrean people in order to realize the GoSE developmental strategy. The MLHW is broadly mandated to protect and care for the welfare of the vulnerable children and families through community based approaches. More over in the different government sectors there are various social protection programmes that 
ensure access to services, such as free medical care and provision of free universal primary education.

The components of social protection, in Eritrea, include social insurance programmesfinanced by contributions and based on insurance principles (pension, health insurance and other social insurance); social assistance to the vulnerable, non-contributory tax-financed benefits in kind and in cash transfers. Non-contributory programmes are essential for reaching the poorest and most vulnerable populations, such as orphans, elderly people, people with disabilities, people living with HIV/AIDS, and those most affected by natural disasters and crisis. They generally aim to reduce poverty and vulnerability and to improve health, education and food security among beneficiaries, but, in some cases, these programmes have also been designed to create productive linkages within local economies. Eritrea has implemented different types of non-contributory interventions, such as public work programmes, social transfers, subsidies, training and programmes to facilitate access to social services and productive activities.

There are also promotive and transformational social assistances (health assistance-reduced fees, provision of free health services; free primary, secondary and tertiary education; school feeding schemes; scholarships and fee waivers; child nutritional support grants; water and sanitation; and access to basic housing); and labour market programs (public works programs, small business/enterprise development, micro-finance and skills training). Social protection plays also a key role for women and men of working age by stabilizing their incomes in the event of unemployment, employment injury, disability, sickness and maternity, and by ensuring that they have at least a basic level of income security. While the labour market serves as the primary source of income security during working life, social protection plays a major role in smoothing incomes and aggregate demand, thereby facilitating structural change within economies.

\section{Who benefits from SP programs?}

In Eritrea the largest numbers of beneficiaries in SP programs are persons with disabilities (PWDs) who constitute about 20 percent of the total beneficiaries. Programs geared towards vulnerable children, women and girls and food insecure households summed together makeup 23.5 percent, while 11.5 percent of the programs are distributed among families of martyrs, the elderly, young people, commercial sex workers and small holding farmers (MLHW, 2019). Around 40 percent of the social protection programs mapped address more than one demographic group at the same time (e.g. children, elderly people, PWDs, and women). Moreover, the targeted demographic categories may overlap: for instance, a program may target children with disabilities or young women. 


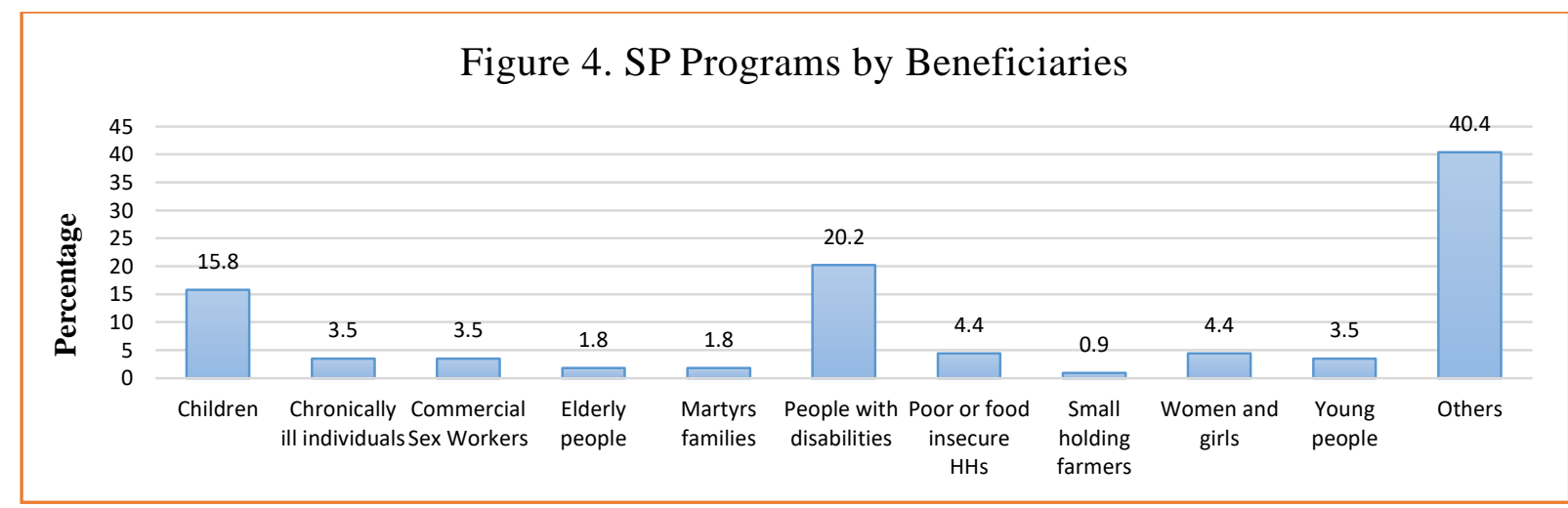

Source: Ministry of Labour and Human Welfare (2019). Mapping/Stock Taking of Social Protection Programs Services in Eritrea. Asmara

Programs to support the elderly and pensioners and to martyrs families each account for 1.8 percent. SP programs that support victims of natural disaster are few in number ( 0.9 percent $)$, relief assistance for victims of natural disaster programs ( 0.9 percent), which is due to the low number of incidents of natural disaster occurring in the country (MLHW, 2019). Even though traditional care and support to elderly is slightly waning (more so in the urban areas), the low number of programs related to the elderly can be explained by the fact that families do play major role in caring and supporting of their elderly parents and keens. The small percentage of SP programs to support martyrs' families is explained by the fact that most of these groups are included in the other SP programs to support disabled and their dependents.

\section{How are SP program beneficiaries selected?}

According to MLHW mapping study of social protection programs in 2019 in Eritrea SP program beneficiaries are selected based on five targeting mechanisms; namely, community based targeting, means test, categorical targeting, geographical targeting, and self-targeting. Community based targeting is used when communities are empowered to identify and select those vulnerable and poor, disabled, etc. and are referred to Sub-Zone or Zone administration to effect delivery of assistance. Out of the 114 programs, 11 programs (9.6\%) use this method. Means test is applied when income or asset of households is considered as basic criteria in selection of beneficiaries. Seven of the programs $(6.1 \%)$ use this criterion to select beneficiaries. Categorical targeting applies when identification and selection is done from certain vulnerable group (children, elderly, single female headed households, people leave with HIV/AIDS etc.) within a community (MLHW, 2019). In eighteen of the programs $(15.8 \%)$ this criterion is used. Geographic targeting applies when beneficiaries are selected from pre-determined locations defined by some kind of unusual occurrence such famine, natural disasters (earthquake, floods, infestation by pests, victims of conflicts). One of the programs falls under this category. Self-targeting is used when individuals apply for support or volunteer to participate in public work program. This is applied in seven programs $(6.1 \%)$. 


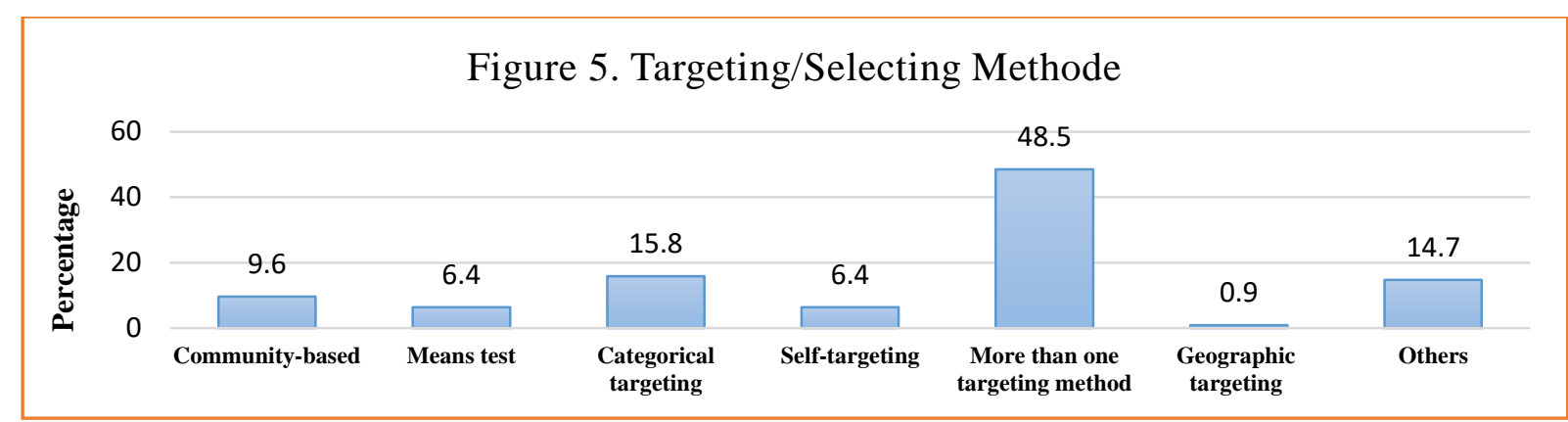

Source: Ministry of Labour and Human Welfare (2019). Mapping/Stock Taking of Social Protection Programs Services in Eritrea. Asmara

As shown in figure 5, around 53.5 percent of the mapped programs rely on one of the above targeting method, and in the remaining 46.5 percent of programs, target beneficiaries are selected using more than one method as they complement each other providing better selection of beneficiaries. The most commonly used targeting methods are categorical and community-based targeting. Key informant interviews and focus group discussions with the service providers indicate that the structure of the local government and government affiliated organizations such as National Union of Eritrean Women (NUEW) and National Union of Eritrean Youth and Students (NUEYS) goes down to the village level making communitybased targeting the relevant targeting strategy in the case of Eritrea.

\section{How are SP programs financed?}

As shown in figure 6, in Eritrea SP programs are financed by government, development partners and community. The government finances about 11.4 percent of the SP programs in Eritrea. More importantly its finance is visible in 42 percent of SP programs (with development partners in 16\%, with communities and development partners in 12 percent, and with communities in 2.6 percent (MLHW, 2019).

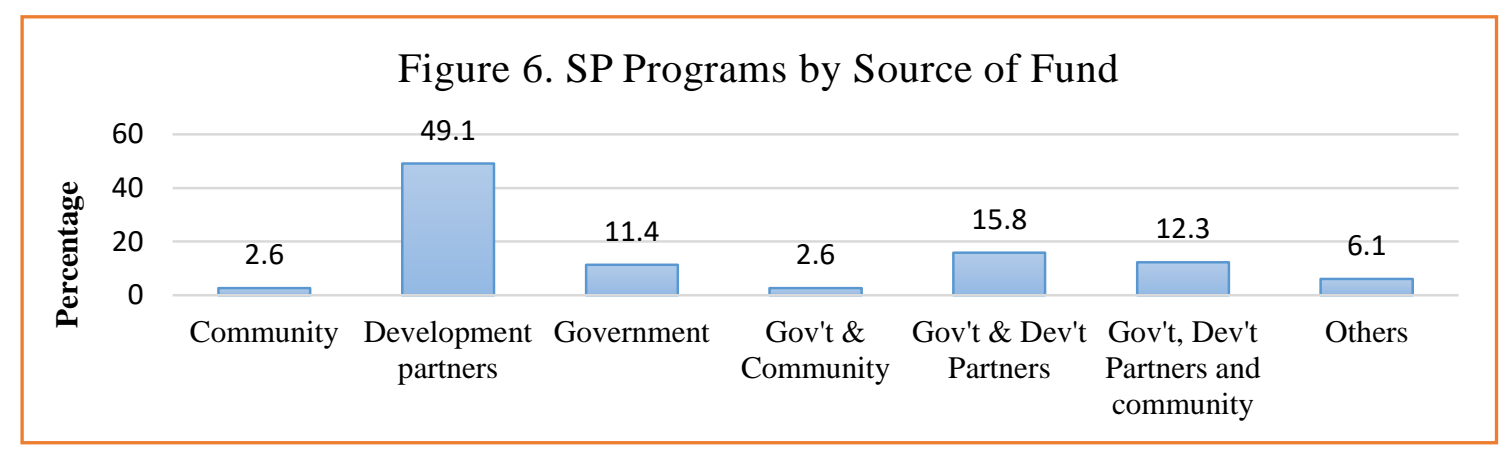

Source: Ministry of Labour and Human Welfare (2019). Mapping/Stock Taking of Social Protection Programs Services in Eritrea. Asmara

Figure 6, further shows that about 13 percent of the 114 SP programs are financed by government, 15.8 percent by government and development partners, and 12.3 percent jointly by government, development partners and communities. It is also found out that about 49 percent of the programs are financed by development partners and 2.6 percent by communities. It should be duly stressed that these figures denote the absolute number of SP programs not the level of financing. The Government finances account for 42.5 percent of the 
total funds expended for SP programs during the period 1992-2017 (MLHW, 2019). The equivalent amount for development partners is 8.6 percent (ibid).

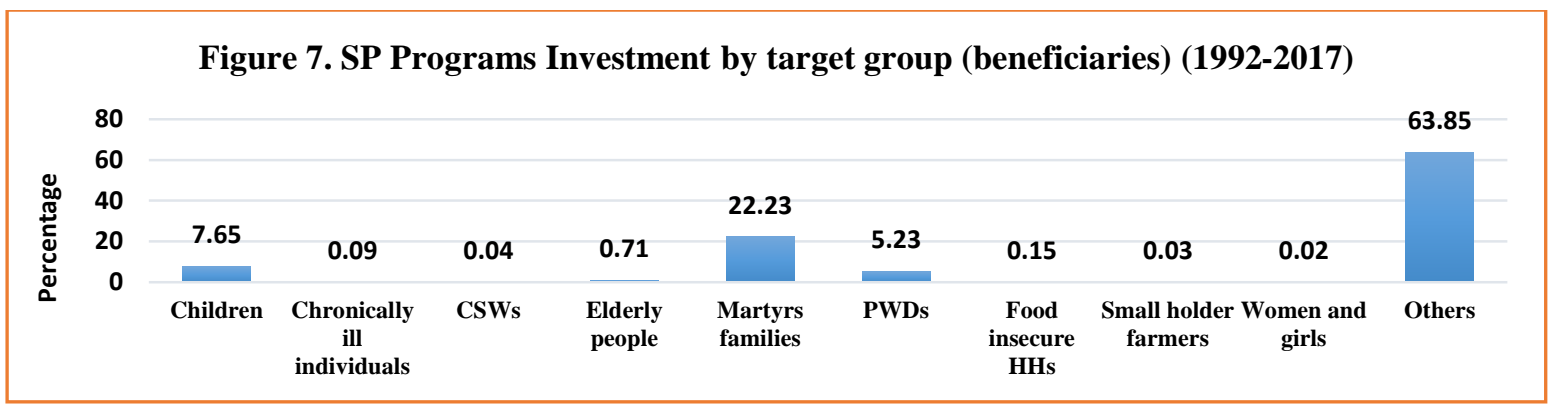

Source: Ministry of Labour and Human Welfare (2019). Mapping/Stock Taking of Social Protection Programs Services in Eritrea. Eritrea-Asmara

As illustrated in figure 7, majority of the SP program investments (about 64 percent) targeted joint beneficiaries like children and care givers, elderly people, persons with disabilities (PWDs) and their dependents, and female headed households and their dependents, People Live with HIV AIDS (PLWHA) and their dependents etc. And about 22 percent of the total fund was invested in interventions supporting martyrs families, 7.7 percent on children and 5.3 percent on PWDs (MLHW, 2019). In the key informant interview the respondents stated that limited number of SP programs or limited funds, posing loss of opportunities for the vulnerable who would otherwise become productive and self-sufficient. For local authorities, it becomes difficult to satisfy demand given the multitude of vulnerable groups.

Long-term sustainability and financing of social protection systems, in Eritrea, is ultimately a political decision and requires the support of both policymakers and the public to underwrite sustained fiscal and political space for a social protection agenda. In the focus group discussions the participants contended that sustainability of SP programs in Eritrea should involve four interacting gears, i.e. human resource capacity, institutional mechanisms, financial resources, and political will. If any of these gears fails to work, the whole social protection capacity development strategy collapses. Therefore, there is a need for the incorporation of SP initiatives within a policy framework to ensure long-term sustainability of social protection, and to permits an efficient interaction of the four gears and systemization of social protection measures.

\section{Types of Social Protection Programs in Eritrea}

As indicated in figure 8 about 79 percent of the social protection systems in Eritrea are distributed among five type of programs: support to persons with disability and their dependents (21.9 percent); social support services (21.9 percent); productive safety nets that enable beneficiaries to earn income (14.9 percent); child protection (11.4 percent); and social transfer, public works and subsidies (9.8 percent) (MLHW, 2019). The 30 years' war for independence and the 1998 border conflict with Ethiopia has resulted in much causality, the victims of which require some means of subsistence. This simply explains the highest number of SP programs recipients to be persons with disabilities and their dependents. Even though the number of SP programs supporting martyrs families is very small, in terms of investment 
it is very large. This is because the 30 years' war and the border conflict (1998-2000) with Ethiopia has left many families to be vulnerable shattering their livelihood.

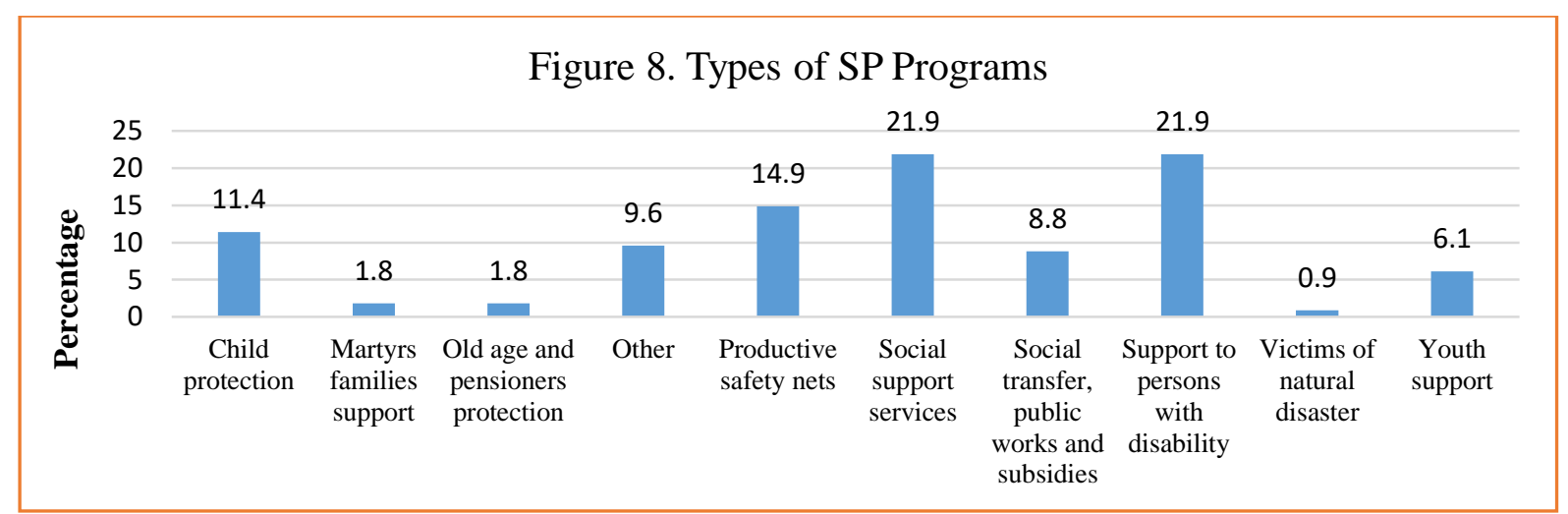

Source: Ministry of Labour and Human Welfare (2019). Mapping/Stock Taking of Social Protection Programs Services in Eritrea. Asmara

The SP programs in Eritrea are combination of a set of 'formal and informal' interventions that aim to reduce social and economic risks, vulnerabilities and deprivations for all people and to facilitate equitable growth. As depicted in figure 9 the social protection systems in Eritrea is further classified in to social care services, social justice, labour market programs, disaster risk management, social insurance (contributory and non-contributory), and social assistance-in kind and cash support, periodic and lump sum payments, means tested and not means tested.

\section{Social Care Services}

Social Care Services are tangible and intangible support/benefits given to people in need. It includes support services in education, health care, water supply, sanitation, residential housing, transport and communication, energy, access to land, agricultural input supplies, soil and water conservation activities, infectious disease management, environmental protection, etc.

\section{Health services}

The GoSE's policy focuses on primary health care as the most appropriate approach to tackle the health problems of the poor and vulnerable groups of the society $(\mathrm{MOH}, 2010)$, with the available limited resources in the face of competing needs. Despite the limitation of resources for health Eritrea is one of the few countries in Africa that achieved the health related MDGs 4, 5 and 6, i.e. reduction of child mortality, maternal mortality and combating HIV and AIDS (MOH, 2014). By 2013, there were 340 heath facilities comprising of 5 referral hospitals, 53 community hospitals, 7 mother-child health clinics, 186 health stations and 44 institutional clinics. There is one referral hospital in each region and one national referral hospital located in the capital city of Asmara. These efforts have not only narrowed the disparities between urban and rural areas in the provision of health services but have also improved access to a health facility to within an average distance of 10 kilometres from any village. The EPHS of 2010 revealed that 75 percent of the Eritrean population live within 10 
kilometres radius of a health facility and 5 kilometres from any health facility (National Statistics Office, 2010).

Figure 9. Social Protection System in Eritrea

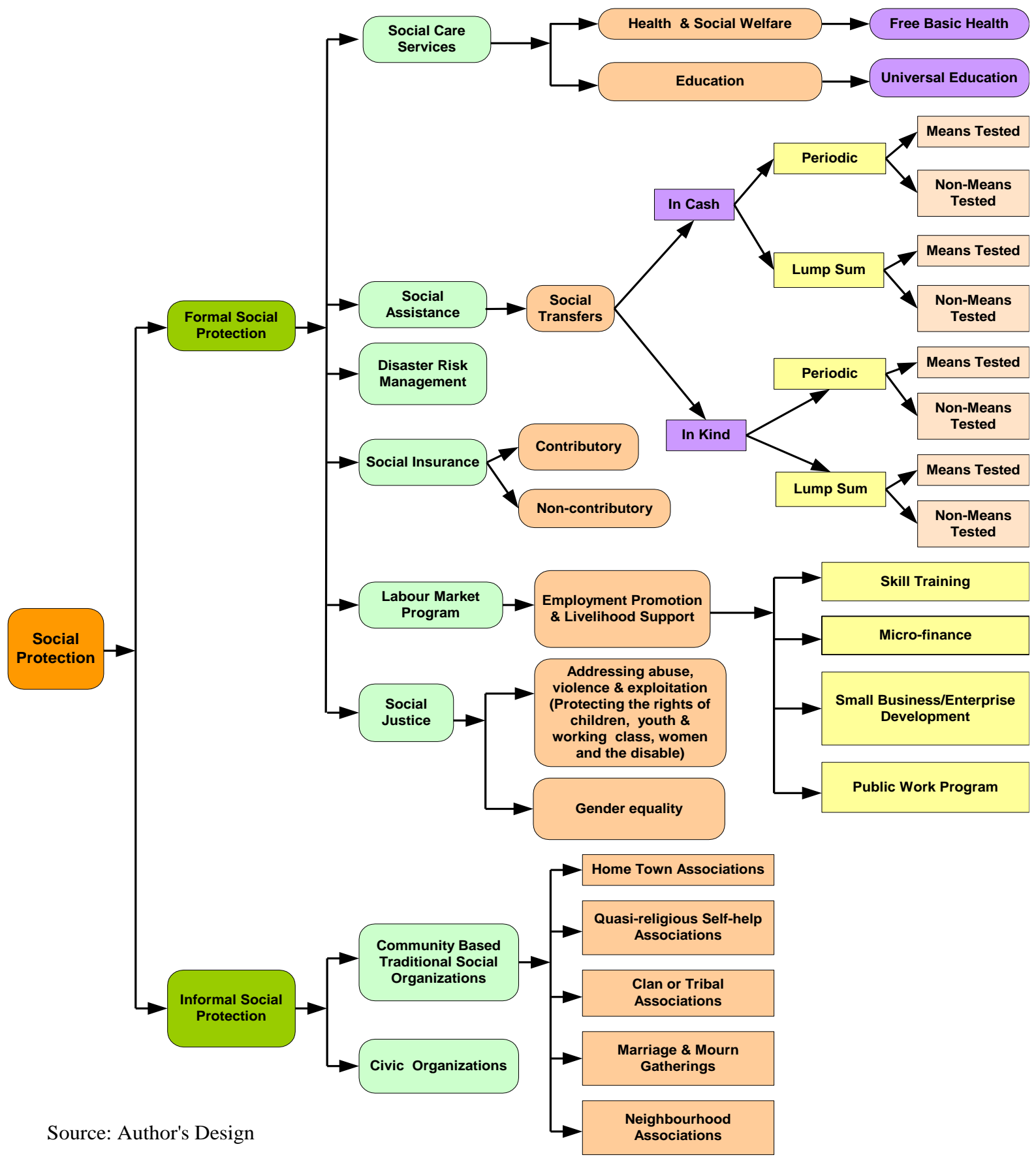

Over the past few years, Eritrea has witnessed significant improvements in life expectancy and in some of the key health impact targets, in particular adult mortality, infant and child mortality, and maternal mortality. Life expectancy at birth has significantly improved from 49 years in 1995 to 64.7 years in 2015, a rate higher than the African region average (WHO, 2016). As shown in figure 10 the trend in maternal mortality, 1990 to 2015 estimates by WHO, UNICEF, UNFPA, World Bank Group and the United Nations Population Division (WHO, 2015), reveals that the Maternal Mortality Ratio (MMR) has declined from 1,590 per 
100,000 live births in 1990 to 501 in 2015, which is projected to 485 deaths per 100,000 live births in 2016. Accordingly, the MMR decreased by 70 percent from 1990 to 2016. The annual rate of reduction for MMR during 1990-2016 is estimated at 4.6 percent.

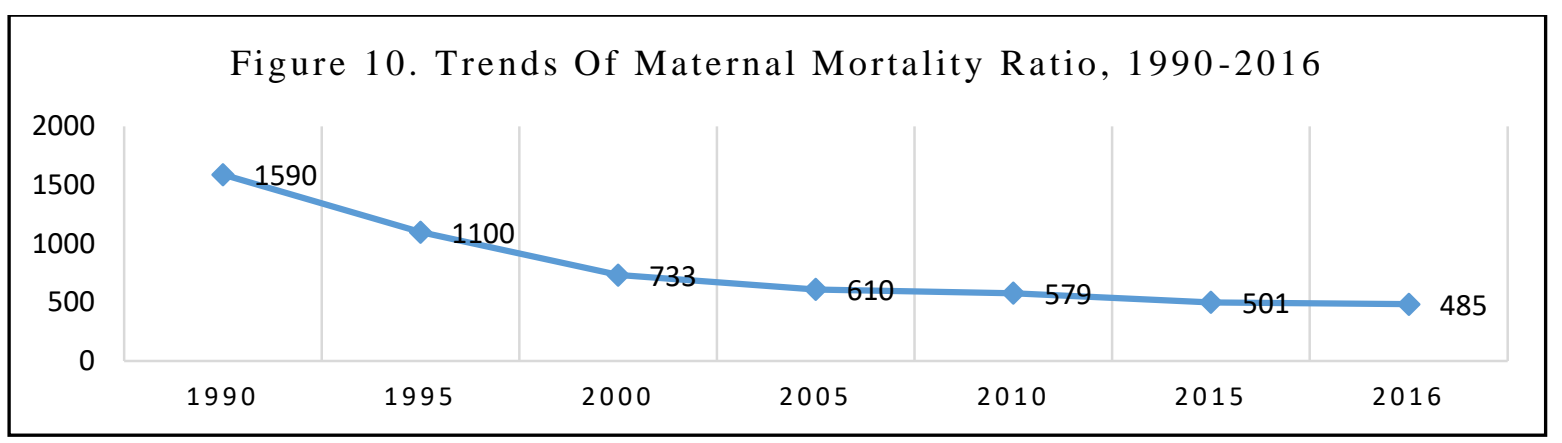

Source: Ministry of Health (2017). Health Sector Strategic Development Plan II (2017-2021)

As it is shown in figure 11 commendable progress has also been attained with child survival, with an annual rate of reduction of under-five mortality from 1990-2016 at 4.8 percent and infant mortality rate reduction from 93 per 1000 live births in 1990 to 34 in 2015, and neonatal mortality reduction from 34 per 1000 live births in 1990 to 18 per 1000 live births in 2015 (MOH, 2017). As shown in the 2015 Report of the UN Inter-agency Group for Child Mortality Estimation, under-five mortality rate was reduced by 68.9 percent from 151 per 1000 live births in 1990 to 47 in 2015 (United Nations, 2015).

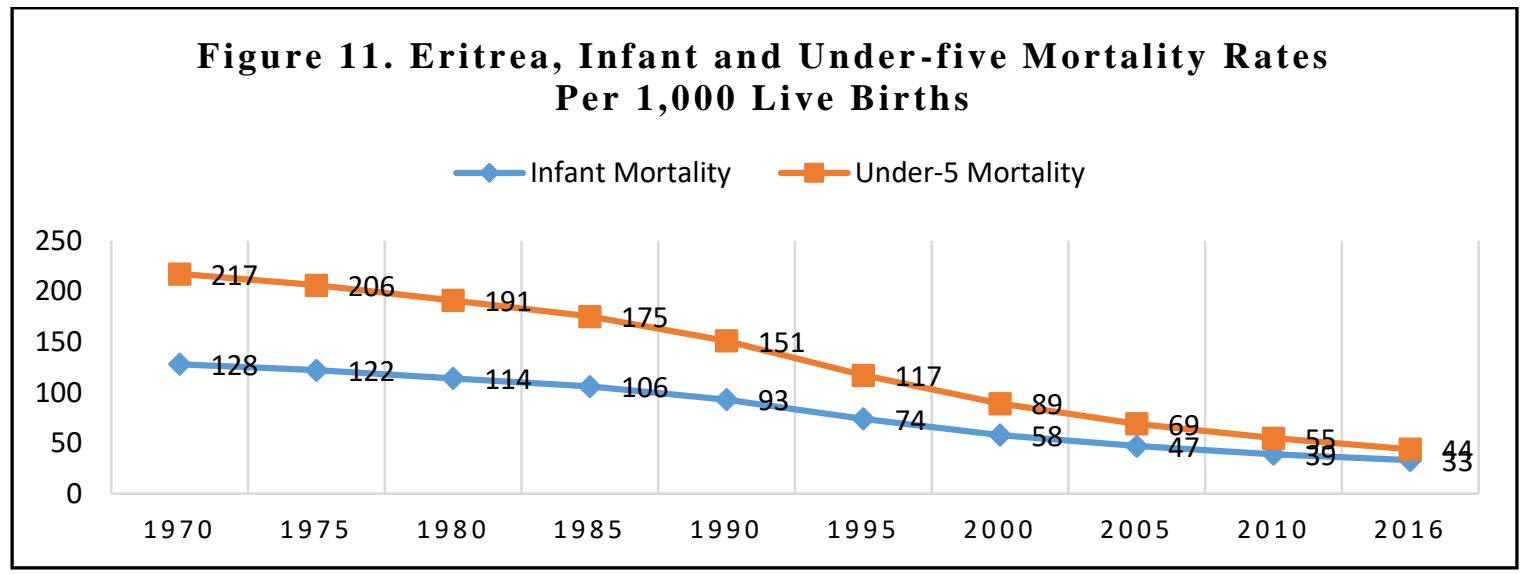

Source: Ministry of Health (2017). Health Sector Strategic Development Plan II (2017-2021)

\section{Education}

In Eritrea, education is seen as the main vehicle for poverty reduction, achieving equity, advancing national values and building national solidarity. Much has been achieved in creating an educational system that responds to the needs expressed by the Eritrean government and the general society. The government, in line with its education policy and all other relevant commitments, is providing free education to all school-age children up to the tertiary level; and hence is striving to achieve national and international targets for Education for All (EFA) and the Sustainable Millennium Development Goals (MDGs). The Ministry of Education (MOE) has revised and up-dated the Education Policy since December 2009, to addresses the educational needs of children. Other educational policy papers and directives 
prepared during the last four years include the Policy and Strategy on Inclusive Education (IE) in Eritrea and The Nomadic Education Policy.

In Eritrea, education is closely linked to virtually all dimensions of development-human, economic, and social. An educated, technically skilled workforce is critical for long-term economic growth. Expanding girls' education has positive effects on fertility, infant mortality, nutrition, and enrolment rates of the next generation. Education is also a key factor in improving governance, as education empowers people, allowing them to develop critical thinking and life skills. In Eritrea education comprises: early child development to ensure the balanced psych motive development of the child through basic nutrition, preventive health, and educational programmes; primary education; secondary education, higher education; vocational and technical education and training; non-formal education and adult programmes; and special education for persons with intellectual or psycho-social disabilities (MOE, 2011).

Significant progress has been achieved with regards to basic education parameters revolving around number of schools, Gross Enrolment Ratio and Net Enrolment Ratio (NER). Hence, the number of primary schools over the years 2000/01-2015/16 increased by $37.8 \%$, and the GER and NER increased from $85.4 \%$ and $58.8 \%$ in $2000 / 01$ to $106.7 \%$ and $82.1 \%$ in $2015 / 16$ respectively (MOE, 2016). In junior and middle school the GER and NER expanded from $62.8 \%$ and $16.7 \%$ in $2000 / 01$ to $75.4 \%$ and $40.9 \%$ in $2015 / 16$ respectively, and the number of secondary schools increased from 43 in 2000/2001 to 104 in 2015/2016 (ibid).

Alongside health and education basic services such as water, energy, and shelter are provided by the GoSE as part of its development and social protection programs. In Eritrea household access to clean and adequate water is presently $65 \%$ and that with access to electricity is $38 \% ; 1100$ new villages provided with access to adequate and safe water; and lots for residential buildings distributed amounted to 128,000 families creating many new urban centers (Habtom, 2021). While much progress has been made in increasing access to basic social services since independence, coverage and quality of social services still need improvement in Eritrea.

\section{Social Assistance}

Social assistances are non-contributory programs funded by the Government of Eritrea (with development partners support). These include predictable cash transfers as well as in kind transfers to the poorest and most vulnerable households, such as fee waivers, school feeding programs, cash transfers to martyrs family, and in kind distribution of subsidized basic food items like bread, cereals, cooking oil, sugar, etc. Community based social welfare programs also target orphans, street children and persons with disabilities and provide support through saving and micro credit, income generating activities and vocational training for the creation of employment opportunities. There are also sectoral social protection policies in health for all, universal education, labour proclamations, child policy, policy for People with Disabilities (PWDs), Pension scheme for civil servants, etc. All of these programs contribute towards the improvement of livelihoods of families and communities and they emanate from the Government's political commitment towards the protection of its citizens from 
vulnerabilities and its dedication to the promotion of the principles of social justice. For instance in the early years of independence, with the limited resources available, the government successfully reintegrated 55,000 combatants into civilian life; resettled about 190,000 returning refugees and helped to take care the families of the tens of thousands of fighters who had died or were disabled during the war of independence (GoSE, 2004). In addition the government distributed food supply to the most needy who lived in drought prone regions.

\section{Social Insurance}

Social insurances are contributory programs that enable contributors to manage risk. These include contributory pension schemes and relevant micro insurance products for workers in the formal and informal sectors. Contributory social insurance schemes minimizes income shocks associated with ill health, unemployment or retirement. In Eritrea contributory social insurance schemes are confined to formal sector government employees. The scheme tend to exclude workers in the informal sector due largely to the fact that productivity level in the informal economy is too low and incomes are irregular making it difficult for workers to enrol in contributory schemes. However, with regards to non-contributory social insurance schemes employees who are working in the formal private sector are entitled to workers compensation for job related injuries, occupational diseases, disability, maternity, and severance pay upon termination of employment (GoSE, 2001). There are also plans to include self-employed and formal private sector employees in the contributory social insurance scheme.

Most of the respondents, however, noted that the social insurance schemes in Eritrea should include unemployment insurance to deal with frictional (sometimes structural) unemployment; work injury insurance to compensate workers for work-related injuries or diseases; disability and invalidity insurance, normally linked to old-age pensions, to cover for full or partial disability; sickness and health insurance to protect workers from diseases; maternity insurance to provide benefits to mothers during pregnancy and post-delivery lactating months; old-age insurance to provide income support after retirement; and life and survivors insurance, normally linked to old-age pension to ensure that dependents are compensated for the loss of the breadwinner. In Eritrea, social insurance is strongly linked to the formalised labour market, meaning that coverage is determined by number of formal workers in a country and rarely reaches the poor and informal workers-often the majority of the population. The informal labour market therefore presents a strong challenge to the success of social insurance programs.

\section{Employment Promotion and Livelihood Support}

Shortage of skills and high unemployment are among the main bottlenecks for inclusive growth in Eritrea. According to the Ministry of Education Sub-Sector Review Report on Technical Vocational Education and Training, over $80 \%$ of Eritrean students do not acquire specific job related skills after high school, thereby increasing youth unemployment. This 
component of social protection, in Eritrea, includes skill training, micro-finance, small business/enterprise development and public work programs.

\section{Skill training}

According to the Eritrea Population and Health Survey (EPHS) 2010, 46\% of the Eritrean population is in the working age (National Statistics Office, 2010). Livelihood enhancement and employment for the working age is one of the key components of the national social protection strategic plan in Eritrea. The national social protection strategic plan involves several activities, which include active labour markets programs i.e. direct employment generation (promoting labour market policies and programs to generate employment opportunities for vulnerable youth through small and medium enterprises, and public works); labour exchanges or employment services (job brokerage, counselling) linking supply with demand for labour; skills development programs (training and retraining of labour through vocational, apprenticeship and internship programs; and establishing youth employment agency to transform youth from a situation of unemployment to employment. The FGD participants, however, noted that linking vocational training to local market needs and the current market situation is not encouraging for product sales.

\section{Micro-finance}

The government's saving and micro credit programme provides credit in all six administrative regions to help women establish small and medium enterprises and thus improve their incomes and their families' economic conditions. These are in addition to other micro-credit programmes specifically targeting women by National Union of Eritrean Women, the Ministry of Local government, Ministry of labour and human welfare (MLHW), the National Confederation of Eritrean Workers (NCEW) and local governments in some regions. During 2009- 12, MLHW gave ERN 137.5 million in loans/credit. The women beneficiaries constituted $24.2 \%$ and satisfactory results have been registered in Gash-Barka. Promoting access to decent jobs for women requires a combination of actions, ranging from macro-economic policies and regulatory frameworks to labour-market policies and targeted interventions directed at disadvantaged groups of young people and women. In the focus group discussions the respondents, however, noted that high interest rate on loans from saving and micro-credit programs (SMCP), which is 16 percent, is affecting the income generating activities of the vulnerable groups.

\section{Public Work Programs}

Taking into account the poor performance of the private sector in Eritrea promotion of public work programs can provide jobs to vulnerable youth and women in rural and urban areas. Public work programs can offer cash or in-kind assets (e.g. food for work, work for cash) to daily labourers or poor farmers who are not in a position to find alternative employment/ livelihood due to short or long-term shock. One rationale behind this initiative is to stabilize the household livelihood so that families can use whatever money saved from food and other purchases for their children's education and health care needs. Experience showed that labour 
intensive public works programs, implemented through the Ministry of Local Government created employment opportunities for the rural poor through the rehabilitation of community assets, including feeder roads, small earth dams and dugouts.

The envisaged activities for the promotion of public work programs include scaling-up and integration of the labour intensive public works to create employment opportunities for the rural and urban poor; introducing labour based cash transfer/public works programs for youths, persons with disabilities and the unemployed; promoting affirmative action for employment of disable youth and women; increasing access to financial services for micro and small enterprises and cooperatives; providing unemployment insurance and non-cash unemployment benefits to job seekers; promoting labour market policies and programs to generate employment opportunities for vulnerable youth; establishing youth employment agency to transform youth from a situation of unemployment to employment through skills training and internship modules; increasing youth access to farm land and agricultural input supplies; promoting agricultural cooperatives through legislation; improving access to financial services for micro and small enterprises and cooperatives; facilitating the implementation of the Minimum Integrated Household Package to boost self- sufficiency in small farm households; providing affordable child care services for children under five to enable parents engage in productive activities; and encourage employers to provide day care and kindergarten services to under five children.

\section{Social Justice}

The primacy of the goal of social justice in Eritrea is to foster fairness and equity in economic, social, and cultural rights of all Eritrean Citizens. Fairness and justice shall underpin the provision of social protection services across different demographic categories and geographical locations irrespective of ethnic origin, gender, possessions, race, and religion. Citizens should be treated equally and without prejudice. Hence the social justice in Eritrea:

(i) addresses violence, abuse, exploitation and providing legal protection and support-this include preventing abuse, violence, and exploitation; providing social services to victims; empowering the most vulnerable groups in society; and encouraging collaboration among multiple stakeholders (government ministries and agencies, regional assemblies, justice and the police) to enhance the rights of vulnerable groups. This include a wide range of activities such as development of national child protection strategy, undertaking outreach programs to support children in the community and in emergency situations, providing health services, psychosocial support, and counselling to survivors of violence against persons, addressing child labour, child abuse, child rape, and human trafficking, and increasing communication/ awareness raising (person to person and mass media) for prevention of abuse, violence, neglect and exploitation; promoting protective legal and policy environment; and establishment of rehabilitation and training centers for juvenile delinquencies.

The Penal Code of Eritrea, the Civil Code of Eritrea and Civil Procedure Code of Eritrea provide the legal basis for the protection and of the rights of children and the general 
population. They recognise that children have the right to know and be cared for by their parents or guardians, have access to education, medical treatment, and protection from all forms of exploitation and abuse, albeit that much more remains to be done to keep abreast with emerging situations dictated by global and regional socio-economic imperatives. Eritrea has also ratified the Child Rights Convention (CRC) of the UN in July 1994. In doing so, the GoSE took on a collective responsibility to respect, protect and promote the rights of children. These responsibilities cut across all the organs of Government, at the national, regional, sub-regional, village community and family levels.

(ii) Focuses on gender equality -promotion of gender equality in Eritrea has a strong historical background dating back to the struggle for independence, when an estimated $25 \%$ to $30 \%$ of the fighting forces were female. Subsequent initiatives have been put in place to ensure gender balance further. The 2003 Eritrean National Education Policy is premised on the principle of equality between men and women. Furthermore, the government has also passed legislation related to gender-sensitive issues such as land legislation, prohibition of female genital mutilation, gender-based violence, and underage marriage, as well as representation in political platforms. Affirmative measures to preserve one-third of seats in elected bodies at various levels continue to be applied. Women now occupy $37.7 \%$ of positions in the local courts, $20 \%$ of ministerial posts, and in 2012, the ratio of women to men in higher government jobs was $26.7 \%$. Overall, $42 \%$ of civil-service employees were female in 2013.

The government of Eritrea ratified the Convention on the Elimination of All Forms of Discrimination against Women (CEDAW, 1995) and translated into local languages. The government has introduced also a National Policy on Gender (NPG 2004), the National Gender Action Plan (NGAP 2003-2008), a separate strategy for female education, a gender awareness strategy of the communities, and an initiative to strengthen collection of disaggregated data for effective monitoring. Eritrea adopted a Female Circumcision Abolition Proclamation in 2007. The creation of National Union of Eritrean Women (NUEW) has provided a mechanism for mobilising women to participate in development initiatives. As of 2014, the union had 300,000 members in the country with offices in all the 6 administrative zones, 56 sub-zones, village levels, and in the diaspora. A unique story is the involvement of Eritrean women in the diaspora in fund-raising for the construction of training centres for women in 5 zones and 11 sub-zones. The Union is also developing the skills of women in rural areas, empowering them economically through micro-finance and creating markets for their products. The presence of the NUEW at all levels makes it effective in outreach, sensitisation, and community mobilisation, although women often face challenges in ensuring that all policies are gender sensitive, especially when it comes to economic empowerment.

\section{Disaster Risk Management}

There are regions in Eritrea where people are injured, affected, and homeless as a result of disasters. Generally, four main types of risk to the poor can be identified: those related to the individual lifecycle, economic, environmental and social/ governance related. Victims of catastrophes are usually assisted by public relief programs; however, given the important 
economic and human loss caused by disasters, the critical issue is to invest in disaster preparedness. Several countries in Sub-Saharan Africa have established disaster management centers for assessing hazards, planning risk reduction and monitoring programs, providing emergency assistance, and strengthening local-level risk reduction capacity.

Preventing vulnerable groups from disasters and shocks is one of the main objectives of social protection system in Eritrea. To achieve its objectives the government is envisaged to adopt two strategies: improving disaster preparedness and management techniques; and strengthening effective coordination of technical support, resource mobilization, and partnership at country level. Both strategies involve several activities, which include clarifying the role of partner institutions and stakeholders; assigning qualified workforce; conducting training to enhance the capacity of the work force; design mitigation strategies; improved hazard forecasting techniques through computer models on climatic change; strengthening early detection and response mechanisms to contain outbreaks; introduction of strong early warning and surveillance system; strengthening the laboratory capacities of health systems; providing adequate supplies and facilities; establishment of rapid response teams; introducing catastrophe prevention mechanisms and mitigation programs including insurance against natural disasters; establishment of national disaster risk management coordination office; designing proactive intervention mechanisms to control the spread of pandemic/epidemic and desert locust; designing multi-sectoral coordination mechanisms to support victims of natural disaster and COVID 19 patients; and introduction of micro and area-based schemes to address vulnerability at the community level, including microinsurance, agricultural insurance, social funds and programs to manage natural disasters.

\section{Informal Social Protection}

In Eritrea, as most informal operators are excluded from coverage, they have evolved for themselves informal arrangements for social protection. In the focus group discussions the participants noted that traditional forms of social protection systems have been used by immediate and extended family members, neighbourhoods, and community based social organizations to help the poor, the orphans, the persons with disabilities and the elderly as part and parcel of their social norms and values that has been going on for generations and are still preserved. Traditional Eritrean societies have always relied on kinship support in times of distress. Families, kinship groups and communities have evolved strategies to meet life contingencies faced by other members.

Eritrean societies have indigenous social welfare systems and ecological coping mechanisms that protect the poor from hunger, starvation, and death even under the most difficult circumstances. Thy have alternative sources of income that includes gold mining, exploitation of sea and forest products, ploughing the field of villagers who have neither animal nor labour to do the job; and collecting water or firewood and selling it in villages and towns. Outside the traditional subsistence economy, coping mechanisms include seeking jobs in towns and neighbouring countries, selling the remaining production assets to keep the 
family alive and selling jewellery that was given to the woman of the household on the occasion of their marriage as last resort.

Informal social protection systems comprise community-based or "traditional approaches" to social protection, often based on kinship, friendship or community links, occurring within households, groups or other social networks, and they fill some of the gaps left by the absence of, or inadequacies in, formal social protection interventions.

Table 2. Informal Social Protection -community based traditional social organizations in Eritrea

\begin{tabular}{|c|c|c|}
\hline $\begin{array}{l}\text { Type of } \\
\text { association }\end{array}$ & Mode of governance & Type of services \\
\hline $\begin{array}{l}\text { Home-town } \\
\text { associations }\end{array}$ & $\begin{array}{l}\text { These associations are formed by a } \\
\text { group of people who descended from } \\
\text { the same village. This association } \\
\text { helps to keep people in touch by } \\
\text { creating a social space with others } \\
\text { coming from the same village and } \\
\text { having the same identity, yet living in } \\
\text { urban areas. Members of the } \\
\text { association contribute a fixed amount } \\
\text { of money periodically (monthly). } \\
\text { These associations are used as a } \\
\text { safety net beside their social and } \\
\text { economic benefits. }\end{array}$ & $\begin{array}{l}\text { - Promote social relations, and } \\
\text { strengthen ties among people } \\
\text { with common identity. } \\
\text { - Develop reciprocity and } \\
\text { exchange among members. } \\
\text { - Provide financial and material } \\
\text { assistance for common festivities } \\
\text { (e.g. wedding and other } \\
\text { ceremonies). } \\
\text { - Provide financial assistance to the } \\
\text { ailing and to the families of the } \\
\text { deceased member. }\end{array}$ \\
\hline $\begin{array}{l}\text { Quasi-religious } \\
\text { self-help } \\
\text { association }\end{array}$ & $\begin{array}{l}\text { These associations are formed by a } \\
\text { group of people who have common } \\
\text { religious believes. } \\
\text { Members of the association } \\
\text { contribute a fixed amount of money } \\
\text { periodically (monthly). The money is } \\
\text { used for financing social events } \\
\text { (marriage and mourn) and for the } \\
\text { assistance of individual members at } \\
\text { times of sudden social crises. }\end{array}$ & $\begin{array}{l}\text { - Provide financial assistance in } \\
\text { time of crises. } \\
\text { - Extend loans to members with no } \\
\text { interest rate. } \\
\text { - Provide financial assistance for } \\
\text { mourn and funeral expenses. } \\
\text { - Provide financial and material } \\
\text { assistance for common } \\
\text { celebrations [e.g. marriage and } \\
\text { other festivities]. }\end{array}$ \\
\hline $\begin{array}{l}\text { Clan or tribal } \\
\text { associations }\end{array}$ & $\begin{array}{l}\text { Clan and/or tribal associations are } \\
\text { organized along extended family } \\
\text { members where all claim a common } \\
\text { genealogical ancestry. At times of } \\
\text { hardship a network of kin or tribe } \\
\text { would be mobilized to provide } \\
\text { assistance, serving as the primary } \\
\text { social safety net. }\end{array}$ & $\begin{array}{l}\text { - Strengthen ties among people } \\
\text { with common genealogical } \\
\text { ancestry. } \\
\text { - Serve as a primary safety net in } \\
\text { times of hardship. }\end{array}$ \\
\hline
\end{tabular}




\begin{tabular}{|c|c|c|}
\hline $\begin{array}{l}\text { Marriage and } \\
\text { mourn } \\
\text { gathering }\end{array}$ & $\begin{array}{l}\text { Social networks and relations are } \\
\text { fostered by the institutions of } \\
\text { marriage and mourn ceremonies. } \\
\text { Social obligation in the attendance of } \\
\text { such social events is enforced } \\
\text { through social norms and sanctions. }\end{array}$ & $\begin{array}{l}\text { - Provide material and financial } \\
\text { assistance. For example, in times } \\
\text { of marriage or morn it is a } \\
\text { common practice for } \\
\text { neighbourhoods, friends, and kin } \\
\text { to extend a helping hand } \\
\text { [material, financial or free } \\
\text { labour] for the affected or } \\
\text { concerned individual in the } \\
\text { locality. }\end{array}$ \\
\hline
\end{tabular}

Neighbourhood These associations are formed by • Provide material and financial associations people who live in the same area assistance for morn and marriage (community). The association ceremonies.

facilitates marriage and mourns - Promotes reciprocity and gatherings, neighbourhood exchange.

cleanliness, celebrations, and other

social events.

Source: Habtom, GK., and Ruys. P., (2007)

Many households in Eritrea deal with economic hardship through informal traditional risksharing arrangements between individuals and communities rather than through publicly managed programs or market-provided insurance schemes. In the traditional Eritrean communities community based traditional associations have three important transactional advantages over the market and the state: adverse selection is limited because community members cannot easily withdraw from the community nor can outsiders become members of the community; communities have generally more information about community members' behaviour than professional insurers or the state; moral hazard behaviour may be especially constrained by feelings of community loyalty; and the ease with which communities can monitor their members' behaviour.

In Eritrea family and community solidarity are important assets in mitigating the consequences of poverty. In the lowlands, family solidarity is traditionally organized; the elderly is looked after by the extended family. In the highlands, while family solidarity is important, community solidarity plays an even more important role, for example, the supportive arrangements among farmers in case of harvest failure (Habtom and Ruys, 2007).

In Eritrea Zakat is also used as a social protection mechanism which is embedded in Islamic religious teaching as one of the five major pillars of Islam and whose aim is to "combat poverty and its effects by collecting and expending the Zakat funds; promoting the spirit of charity and benevolence; and directly addressing poverty and its causes". This mechanism is neither recognised by the government nor by donors and other as an integral part of the traditional Eritrean society social protection response.

Traditional support systems are valuable and beneficial social protection mechanisms as they define personal and collective identity. They are institutions of first instance for support to 
vulnerable persons which provide immediate, more effective, and culturally familiar support. The traditional support system in Eritrea include family and clan support systems, local credit and savings groups, mutual assistance schemes and burial groups, home-town associations, quasi-religious self-help associations, marriage and mourn gathering, clan or tribal associations, and neighbourhood associations. However, the support services received by community members through these initiatives are inadequate and cover only a small proportion of the population, leaving the majority without access to any form of social protection services. So there is a need for government intervention to expand coverage and capacity of the aforementioned traditional support systems.

\section{Discussion}

The primary purposes of social protection are to prevent, mitigate and enhance the ability to cope with and recover from the major hazards faced by all poor people; to contribute to chronically poor people's ability to emerge from poverty, deprivation and insecurity, and to challenge the oppressive socio-economic relationships which could be keeping them poor, by increasing livelihood security and linking such increases to the promotion of enhanced livelihoods; and to enable the less active poor to live a dignified life with an adequate standard of living, such that poverty is not passed from one generation to the next. Social protection also supports economic growth, social integration and political stability, human development, and human rights objectives.

It is encouraging to note that one of the most important developments, in Africa, over the last years is the progressive inclusion of the self-employed in the social security schemes. Selfemployed persons and members of their family living in the house, other than their dependants were insured under the same conditions as employed persons. There are also possibilities of insuring persons against sickness and maternity necessitating hospitalisation, sickness which has lasted for several months, and extraordinary expenses incurred in cases of sickness, maternity, invalidity and death. Similarly the Eritrean government has also implemented different types of non-contributory interventions, such as public work programmes, social transfers, subsidies, training and programs to facilitate access to social services and productive activities. Public works programs have the potential to address vulnerabilities, but they are currently fragmented, limited in coverage and do not guarantee regular and predictable minimum level of income for vulnerable households. The programs usually focus on construction of community roads and provide one-off benefits to the communities.

Social care and support services in Eritrea are based on traditional social networks, particularly the family and the community. However, over time these networks have been strained by HIV and AIDS, conflicts, rural-urban migration and poverty, among others. This has compelled government and civil society organizations (CSOs) to play an increasing role in providing social care services. Existing formal social care and support services include resettlement of abandoned and street children, care and protection of children in conflict with the law, institutional support to vulnerable children, PWDs and older persons, care and support to gender-based violence victims/ survivors, community-based rehabilitation for 
PWDs, community-based care and support for older persons. However, in the research it was found that considering the high number of vulnerable groups in the country, these services are limited in scope and coverage, grossly underfunded and poorly coordinated. Social care and support services handled by the Community- Based Services Department in the Local Governments have inadequate human resource and logistical capacity for effective service delivery. CSOs usually concentrate on a small geographical area and select a few communities from an entire district, and most of them operate in isolation, making coordination, supervision, monitoring and evaluation of their activities very difficult for both Central and Local Governments. The weak coordination of services delivered by CSOs leads to duplication of efforts, wastage of resources and minimal impact on the population. Furthermore, the voluntary social welfare workers are overloaded and overstretched. They lack adequate financial resources to offer effective services to scattered settlement of communities in the low land areas of Eritrea.

In the key informant interview and focus group discussions the respondents noted that there is a need for the creation of a public-private partnership in the delivery of social protection services in order to obtain synergies and gains for the poor. Public-private partnerships are institutional relationships between the state and the private for-profit and/or the private not for-profit sector, where the different public and private actors jointly participate in defining the objectives, the methods and the implementation of an agreement of cooperation (Schmidt, et.al. 2005).There are theoretically sound reasons to expect potential favourable effects from this cooperation and there are positive cases to illustrate the point (ibid). To enhance efficiency and effectiveness the government should use the four main social service delivery mechanisms: public sector-based, through central line ministries and local governments, normally best to achieve expansion of coverage and to reduce poverty and social exclusion nation-wide; market-based, normally good for efficient delivery of services to higher income groups; NGOs and charitable institutions, normally good for working with communities; and a mix of the above - given the scarcity of resources for social policies in developing countries, a best solution may be a mixed delivery system (Ortiz, 2007).

In most African countries the economic and social impacts of COVID-19 pandemic are addressed through public-private partnership. Nowadays governments are facing a double challenge: they have to contain the health pandemic, while at the same time responding to its economic and social impacts. Social protection systems are an indispensable part of a coordinated policy response to the unfolding crisis, ensuring that people can effectively access health care while supporting job and income security for those most affected. They increase resilience, contribute to preventing poverty, unemployment and informality and are powerful economic and social stabilizers that can contribute to a swift recovery. Social dialogue and consultations with social partners and other stakeholders are particularly important for such coordinated policy responses.

\section{Conclusion}


In Eritrea, the main sources of vulnerability are external and internal shocks that include: (a) food insecurity (due to drought, pest infection, or military conflict); (b) single source of income and employment (agriculture based source of livelihood is vulnerable to drought, pests, degradation of natural resources and fragmentation of small holder farms); (c) lack of access to and poor quality of basic social services and infrastructure (in particular water during drought conditions); (d) lack of access to productive assets (land, credit and farm equipment) and markets; and (e) lack of adequate social safety nets to protect the socially and economically vulnerable.

The social protection system in Eritrea has major challenges, among others which include the following: lack of integration of social protection into national plans-as a result social protection is not broad based to target all areas of vulnerability; lack of a comprehensive plan on the implementation of social protection programs; poor inter-sectoral coordination and collaboration with civil society; inadequate budget allocations to social protection and poor mobilization of resources as a result the funding is not sustainable and is not adequate for scaling up; low technical and institutional capacity to develop social protection programs and to administer some social protection programs; lack of reliable data on which policies on social protection could be based, limited information dissemination on availability of existing social protection programmes; and lack of effective monitoring and evaluation systems on SP programs. The current $M \& E$ arrangements for social protection interventions are inadequate and comprise only few functional systems. They are characterized by fragmentation, duplication, and poor co-ordination, absence of clear results chain and lack of tracking and reporting of outcomes. In most cases reports use different formats and approaches with no common guidelines and standards. Moreover, there is inadequate feedback and sharing of information and results across public organizations and other stakeholders. There is a need for government's intervention to manage cooperation across ministries and to build integrated capacity for comprehensive social protection systems.

To address the basic needs of the poor and vulnerable population the FGD participants suggested for the introduction of a set of fast high impact SP programs. These programmes contain components such as: food stamps, free school meal programmes, nutrition supplements for mothers and children; emergency employment programmes; upgrading programmes for substandard housing (water, sanitation, energy efficiency, household repairs); free access to basic health and essential drugs; literacy campaigns, expansion of free basic education for all; conditional cash transfers to ensure student retention in schools and child vaccination; and unconditional cash transfers such as pensions for the elderly poor or persons with disabilities. These programmes involve multi-sector interventions, and can be additionally used as an instrument to start mainstreaming equity across sectors.

In the key informant interviews and focus group discussions the respondents further noted that there is a need for government intervention in five priority areas of social protection. These are (1) designing of labour market policies and programs to generate employment, improve working conditions and promote the efficient operations; (2) enhancing social insurance programs to cushion the risks associated with unemployment, ill health, disability, work-related injury and old age; (3) promoting social assistance and welfare service programs 
to provide support for the vulnerable groups with inadequate means of income, including single mothers, the homeless, or physically or mentally challenged people; (4) expansion of micro and area-based schemes to address vulnerability at the community level, including micro-insurance, agricultural insurance, social funds and programs to manage natural disasters; and (5) supporting child protection services to ensure the healthy and productive development of children.

Most of the respondents emphasized on labour market interventions as it provides protection for poor people who are able to work. In this case interventions can be both active and passive: active programmes include training and skills development and employment counselling, whilst passive interventions include unemployment insurance, income support and changes to labour legislation, for example in establishing a minimum wage or safe working conditions. Labour market interventions can run alongside various social assistance and cash transfer programmes and can be integrated into longer-term development strategies.

\section{Lessons learned}

1. Strong governmental capacity at national and local levels is required for appropriate design, effective implementation and robust financial management of national social protection policies, programmes and systems.

2. There is considerable interest in the potential for community-based mechanisms to be scaled up in order to undertake wider development activities, and in creating links between social security schemes and community-based approaches with the aim of extending coverage to meet the challenge of providing adequate social protection services to the developing world.

3. Families and communities awareness about the rights of children, persons with disabilities, the elderly and other vulnerable segments of the society should be strengthened to enhance effectiveness of preventive programs including the deterrence of harmful traditional practices and the preservation of positive social values among children and adolescents.

4. Adopt and implement broad-based social protection policies to mitigate and counteract all sources of vulnerability including chronic crop failures, health epidemics, environmental disasters and other external shocks, and align social protection programs to family policy on education, health, housing and food security.

5. Address urgent social needs through adequate social protection and multi-sectoral programs and promote public-private partnership in the delivery of social protection services in order to obtain synergies and gains for the poor.

6. Traditional support systems are valuable and beneficial social protection mechanisms as they define personal and collective identity. They are institutions of first instance for support to vulnerable persons which provide immediate, more effective, and culturally familiar support. So there is a need for government intervention to expand coverage and capacity of the traditional support systems.

7. The high child/adult dependency ratios of Eritrea, (42.2 percent of the Eritrean population is below 15 years of age and 6.7 percent is 65 years and above, results in age dependency ratio of 96 percent), indicated that there is a need to provide social protection for the 
young, such as early child development to ensure the balanced psychomotive development of the child through basic nutrition, preventive health, and educational programs; school feeding programs, scholarships, or school fee waivers; waiving of fees for mothers and children in health services; street children initiatives; child rights advocacy/awareness programs against child abuse, child labor etc; youth programs to avoid social anomia in teenagers, criminality, sexually transmitted diseases such as HIV/AIDS, early pregnancies, and drug addiction; and family allowances, either meanstested cash transfers or coupons/stamps for basic goods and services (i.e., food, clothing) to assist families with young children to meet part of their basic needs.

\section{References}

1) Adato $M$ and J Hoddinott, (2008). Social Protection Opportunities for Africa, IFPRI Policy Brief No. 5. Asian Development Bank, 2001, Social Protection Strategy, Manila.

2) Baah, Y. A. (2007). Organizing the Informal Economy: Experience and Lessons from Asia and Africa (Ghana TUC, LOFTF (Denmark) Project), Accra: Ghana TUC.

3) Cirillo. C. and Tebaldi, R. (2016).Social Protection in Africa: Inventory of NonContributory Programs. International Policy Centre for Inclusive Growth. United Nations Development Programme

4) Ellis, F., Devereux, S. and White, P. 2009. Social Protection in Africa. Cheltenham: Edward Elgar.

5) François-Xavier Merrien, (2013). Social Protection as Development Policy: A New International Agenda for Action. International Development Policy | Revue internationale de politique de développement [Online], 5.1 | 2013, Online since 10 June 2013, connection on 21 June 2013. URL : http://poldev.revues.org/1525 ; DOI : 10.4000/poldev. 1525

6) Government of the State of Eritrea (GoSE), (2004). Interim Poverty Reduction Strategy Paper (I-PRSP). Asmara-Eritrea.

7) Government of the State of Eritrea (GoSE) (2001). The Labour Proclamation of Eritrea-Proclamation No. 118/2001. Gazette of Eritrean Laws. Asmara-Eritrea.

8) Habtom, GK. (2021). Reviewing Decades of Civil Service Reforms in Sub-Saharan Africa-Drawing Lessons for Eritrea. International Journal of Public Administration and Management Research (IJPAMR), Vol. 6, No. 1. Available online at http://www.rcmss.com/index.php/ijpamr; www.academix.ng

9) Habtom, GK., and Ruys. P., (2007). Traditional risk-sharing arrangements and informal social insurance in Eritrea. Health Policy 80 (2007) 218-235. Available online at http://www.elsevier.com/locate/healthpol

10) Haddad, L. (2007), Comment on 'The Role of Social Risk Management in Development: A World Bank View, Institute for Development Studies.

11) HelpAge International and African Union, (2008). Investing in Social Protection in Africa: Summary report of national consultations held in Burkina Faso, Cameroon, Mozambique, Rwanda, Sierra Leone and Tunisia, London. 
12) Holmes $R$ and A. Jackson, (2008). Cash transfers in Sierra Leone: Are they appropriate, affordable or feasible?, ODI Project Briefing Number 8, London.

13) Holzmann, R. and V. Kozel (2007).The Role of Social Risk Management in Development: A

14) World Bank View, Institute of Development Studies.

15) Horman Chitonge (2012): Social Protection Challenges in Sub-Saharan Africa: 'Rethinking Regimes and Commitments', African Studies, DOI:10.1080/00020184.2012.740878

16) ILO (2000). World Labour Report: Income security and social protection in a changing world, Geneva.

17) ILO. (2008). 'Can Low-Income Countries Afford Basic Social Security?' Social Security Policy Briefing Paper 3. Geneva: International Labour Office.

18) ILO. (2010). Extending Social Security to All: A Guide Through Challenges and Options. Geneva: International Labour Office.

19) ILO (2014), World Social Protection Report 2014/15: Building economic recovery, inclusive development and social justice, ILO, Geneva.

20) ILO and UN Development Group (2016). UNDG Eastern and Southern Africa social protection issues brief. International Labour Office, Social Protection Department; United Nations Development Group - Geneva

21) ISSA. 2008. Dynamic Social Security for Africa: An Agenda for Development. Geneva: ISSA.

22) Kabeer N, (2006), Social Exclusion and the MDGs: The challenge of durable inequalities in the Asian context, Background paper prepared for The Asia 2015 conference, held in London on 6-7 March 2006.

23) Mchomvu, A.S.T., Tungaraza, F.S.K. and Maghimbi, S. (2002): Social security systems in Tanzania, Journal of Social Development in Africa, VOL 17 NO 2 JULY 2002 ,

24) Ministry of Health (MOH) (2017). Health Sector Strategic Development Plan II (2017-2021), Asmara-Eritrea

25) Ministry of Health (MOH) (2010). National Health Policy. Asmara, Eritrea

26) Ministry of Health (MOH) (2014). Annual Health Service Activity Report. Asmara, Eritrea

27) Ministry of Health (MOH) (2017). Health Sector Strategic Development Plan II (2017-2021). Asmara, Eritrea

28) Ministry of Labour and Human Welfare (MLHW) (2019). Mapping/Stock Taking of Social Protection Programs Services in Eritrea. Asmara, Eritrea

29) Ministry of Labour and Human Welfare (MLHW) (2018). Eritrea Labour Force Survey 2015/2016. Asmara, Eritrea

30) Ministry of Education (MOE) (2011). National Education Policy. Asmara, Eritrea

31) Ministry of Education (MOE) (2016). Eritrea Basic Education Statistics 2015/2016. Asmara, Eritrea

32) Naicker P and U. Mguye, 2006, Provision of Social Protection in South Africa, paper presented at a Sida Seminar on Social Policy in a Development Context: Lessons 
from UNRISD Research 2000-2005 on how research can be translated into policies and action, held in Stockholm, Sweden, 31 October 2006.

33) National Statistics Office (NSO) (2010). Eritrea Population and Health Survey. Fafo Institute for Applied International Studies, OSLO, Norway.

34) Nino-Zarazua, M., Barrientos, A., Hulme, D. and Hickey, S. 2010. 'Social Protection in Sub-Saharan Africa: Will the Green Shoots Bloom?' Munich Personal RePec Archive (MPRRA) Paper 22422 /Brooks World Poverty Institute (BWPI).

35) Norton A, T Conway, M Foster, 2001, Social Protection concepts and approaches: Implications for policy and practice in international development, ODI Working paper number 143, London.

36) Ortiz, Isabel. (2007). Social policy. UN DESA Policy Notes. New York.

37) Schmidt, Jean-Olivier, Schramm, B.,Hohmann, J.,Holst, J. Jowett, M., Ramm, G., and Siegert, N., (2005). Linking up social protection systems in developing countries: Overview of some experiences and approaches. gtz/ Bundesministerium fur wirtschafliche Zusammenarbeit und Entwicklung

38) Taylor V, (2008). The study on social protection systems in Africa: An overview of the challenges, Paper prepared for the First Session of the AU Conference of

39) Ministers in charge of social development held from 27 to 31 October 2008 in Windhoek, Namibia.

40) OECD (2019). Implementing social protection strategies. Lessons from the European Union Social Protection Systems (EU-SPS) Programme, OECD.

41) Otoo, KN \& Clara Osei-Boateng (2012). Social Protection Schemes in Africa, Edited by Trywell Kalusopa, Rudi Dicks, and Clara Osei-Boateng. http://www.itcu-africa.org

42) UN, (2001). Enhancing social protection and reducing vulnerability in a globalizing world: Report of the Secretary General presented to the $39^{\text {th }}$ Session of the Economic and Social Council, E/CN.5/2001, New York.

43) UN, (2015). UN Interagency Group for Child Mortality (UNIGME).

44) United States Social Security Administration, (2007). Social Security Programs throughout the World: Africa 2007, Washington DC.

45) Weeks, J. (2007). Pro-Poor Growth: Equity and Poverty Reduction, Paper in training module prepared for United Nations Department of Economic \& Social Affairs UNDP Regional Bureau for Africa, New York.

46) World Bank (2012), World Bank 2012-2022 Social Protection and Labour Strategy. Resilience, Equity, and Opportunity, World Bank, Washington DC, p135.

47) World Bank (2002). World Development Report. New York, Oxford University Press

48) World Health Organization (WHO) (2016). World Health Statistics: Monitoring Health for the SDGs.

49) World Health Organization (WHO) (2015). United Nations Population Division. 